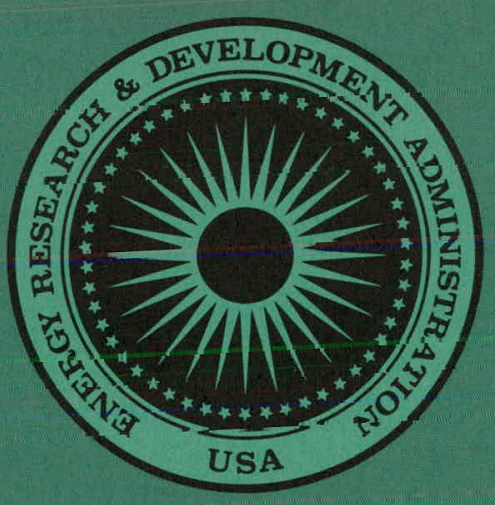

BERC/TPR-77/3

THERMODYNAMICS OF AQUEOUS SODIUM DODECYL SULFATE

By

Robert L. Berg

Date Published-August 1977

Bartlesville Energy Research Center

Energy Research and Development Administration

Bartlesville, Oklahoma 


\section{DISCLAIMER}

This report was prepared as an account of work sponsored by an agency of the United States Government. Neither the United States Government nor any agency Thereof, nor any of their employees, makes any warranty, express or implied, or assumes any legal liability or responsibility for the accuracy, completeness, or usefulness of any information, apparatus, product, or process disclosed, or represents that its use would not infringe privately owned rights. Reference herein to any specific commercial product, process, or service by trade name, trademark, manufacturer, or otherwise does not necessarily constitute or imply its endorsement, recommendation, or favoring by the United States Government or any agency thereof. The views and opinions of authors expressed herein do not necessarily state or reflect those of the United States Government or any agency thereof. 


\section{DISCLAIMER}

Portions of this document may be illegible in electronic image products. Images are produced from the best available original document. 


\section{NOTICE}

This report was prepared as an account of work sponsored by the United States Government. Neither the United States nor the United States Energy Research and Development Administration, nor any of their employees, nor any of their contractors, subsontractors, or their employees, makes any warranty, express or implied, or assumes any legal liability or responsibility for the accuracy, completeness nr usefulness of any information, apparatus, product or process disclosed, or represents that its use would not infringe privately owned rights.

Availahle from the National Technical Information Service, U.S. Department of Commerce, Springfield, Virginia 22161.

NATIONAL TECHNICAL INFORMATION SERVICE PAPER COPY PRICES

$$
\text { EFFECTIVE JAN. } 1,1976
$$

$\begin{array}{ccccccccccccc}\begin{array}{c}\text { Page } \\ \text { range }\end{array} & \begin{array}{c}\text { Domestic } \\ \text { price }\end{array} & \begin{array}{c}\text { Page } \\ \text { range }\end{array} & \begin{array}{c}\text { Domestic } \\ \text { price }\end{array} & \begin{array}{c}\text { Page } \\ \text { range }\end{array} & \begin{array}{c}\text { Domestic } \\ \text { price }\end{array} & \begin{array}{c}\text { Page } \\ \text { range }\end{array} & \begin{array}{c}\text { Domestic } \\ \text { price }\end{array} & \begin{array}{c}\text { Page } \\ \text { range }\end{array} & \begin{array}{c}\text { Domestic } \\ \text { price }\end{array} & \begin{array}{c}\text { Page } \\ \text { range }\end{array} & \begin{array}{c}\text { Domestic } \\ \text { price }\end{array} \\ 001-025 & \$ 3.50 & 126-150 & \$ 6.00 & 251-275 & \$ 9.00 & 376-400 & \$ 10.75 & 501-525 & \$ 12.75 & 701-800 & \$ 18.75 \\ 026-050 & \$ 4.00 & 151-175 & \$ 6.75 & 276-300 & \$ 9.25 & 401-425 & \$ 11.00 & 526-550 & \$ 13.00 & 801-900 & \$ 21.25 \\ 051-075 & \$ 4.50 & 176-200 & \$ 7.50 & 301.325 & \$ 9.75 & 426-450 & \$ 11.75 & 551-575 & \$ 13.50 & 901-1000 & \$ 23.75 \\ 076-100 & \$ 5.00 & 201-225 & \$ 7.75 & 326-350 & \$ 10.00 & 451-475 & \$ 12.00 & 576-600 & \$ 13.75 & 1001-1100 & \$ 28.25 \\ 101-125 & \$ 5.50 & 226-250 & \$ 8.00 & 351-375 & \$ 10.50 & 476-500 & \$ 12.50 & 601-700 & \$ 16.25 & 1101-1200 & \$ 32.75\end{array}$

For additional pages, add $\$ 4.50$ for each beginning 100 pages. Add $\$ 2.50$ per copy for foreign price.

Microfiche $\$ 3.00$ (domestic) $\$ 4.50$ (foreign). 
By

Robert L. Berg

Bartlesville Energy Research Center

Bartlesville, Oklahoma

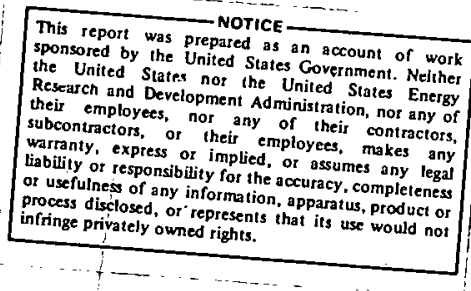

sponsored by the United States an account of work the United States Energy sheir employees, nor administration, nor any of ex, or their employes contractors of useful ot responsibility for the or ossumes any lega process disclosed any information, apparatus, product or 


\section{CONTENTS}

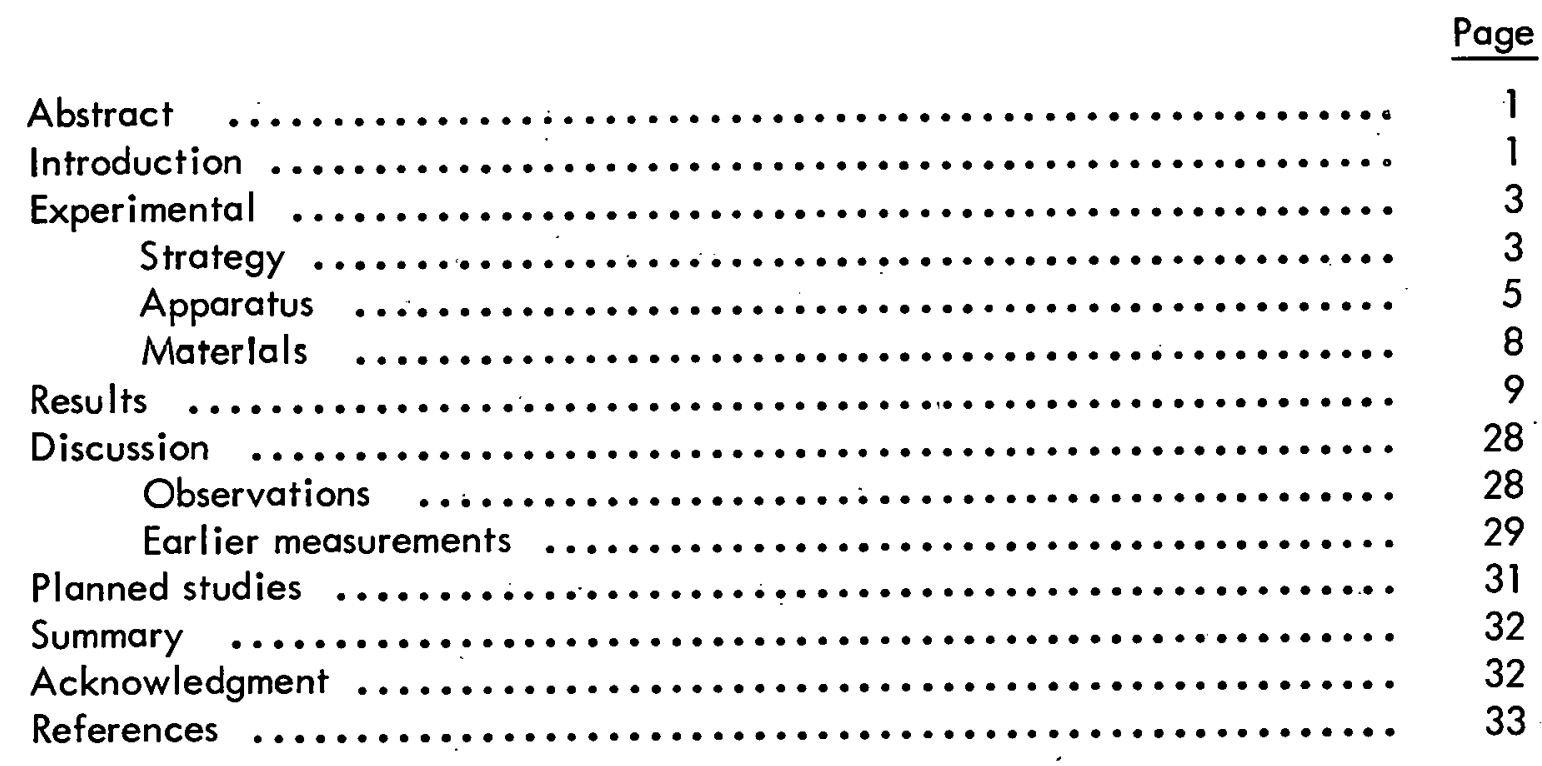

\section{ILLUSTRATIONS}

1. Flow microcalorimeter system $\ldots \ldots \ldots \ldots \ldots \ldots \ldots \ldots \ldots \ldots \ldots \ldots \ldots \ldots . \ldots$

2. Modified amplification system $\ldots \ldots \ldots \ldots \ldots \ldots \ldots \ldots \ldots \ldots \ldots \ldots \ldots \ldots$

3. Sodium dodecyl sulfate enthalpy curves at various temperatures ..... 26

4. Sodium dodecyl sulfate enthalpy curves in salt background ........ 26

5. Sodium dodecyl sulfate enthalpy curves in high salt concentration

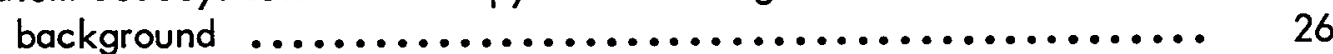

6. Sodium dodecyl sulfate enthalpy curves in 5 percent $n$-butanol ..... 27

7. Sodium dodecyl sulfate enthalpy curves in 5 percent $i$-propanol ..... 27

8. Sodium dodecyl sulfate below the cmc ................... 27

9. Sodium dodecyl sulfate enthalpy curve at $20^{\circ} \mathrm{C} \ldots \ldots \ldots \ldots \ldots$

\section{TABLES}

1. Experimental values of relative apparent molar enthalpies, $L_{\phi}$, for sodium dodecyl sulfate in $\mathrm{H}_{2} \mathrm{O}$ at $20^{\circ} \mathrm{C} \ldots \ldots \ldots \ldots \ldots \ldots \ldots . . . \ldots$

2. Experimental values of relative apparent molar enthalpies, $L_{\varnothing}$, for sodium dodecyl sulfate in $\mathrm{H}_{2} \mathrm{O}$ at $25^{\circ} \mathrm{C} \ldots \ldots \ldots \ldots \ldots \ldots . . . \ldots$

3. Experimental values of relative apparent molar enthalpies, $L_{\phi}$, for sodium dodecyl sulfate in $\mathrm{H}_{2} \mathrm{O}$ at $30^{\circ} \mathrm{C} \ldots \ldots \ldots \ldots \ldots \ldots . . . \ldots$

\section{6} 6 26

28

4. Experimental values of relative apparent molar enthalpies, $L_{\phi}$, for

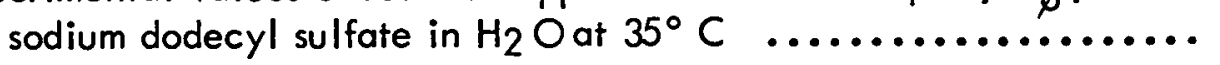




\section{TABLES-Continued}

Page

5. Experimental values of relative apparent molar enthalpies, $L_{\varnothing}$, for sodium dodecyl sulfate in $0.001 \mathrm{~m} \mathrm{NaCl}$ at $20^{\circ} \mathrm{C} \ldots \ldots \ldots . .$.

6. Experimental values of relative apparent molar enthalpies, $L_{\phi}$, for sodium dodecyl sulfate in $0.01 \mathrm{~m} \mathrm{NaCl}$ at $20^{\circ} \mathrm{C} \ldots . . . . . . .$.

7. Experimental values of relative apparent molar enthalpies, $L_{\varnothing}$, for sodium dodecyl sulfate in $0.001 \mathrm{~m} \mathrm{NaCl}$ at $30^{\circ} \mathrm{C} \ldots \ldots . . . .$.

8. Experimental values of relative apparent molar enthalpies, $L_{\phi}$, for sodium dodecyl sulfate in $0.01 \mathrm{~m} \mathrm{NaCl}$ at $30^{\circ} \mathrm{C} \ldots \ldots \ldots \ldots . . . .17$

9. Experimental values of relative apparent molar enthalpies, $L_{\phi}$, for sodium dodecyl sulfate in $0.01 \mathrm{~m} \mathrm{NaBr}$ at $30^{\circ} \mathrm{C}$

10. Experimental values of relative apparent molar enthalpies, $\mathrm{L}_{\phi}$, for sodium dodecyl sulfate in 5 percent $n$-butanol at $20^{\circ} \mathrm{C} \ldots \ldots$

11. Experimental values of relative apparent molar enthalpies, $L_{\phi}$, for sodium dodecyl sulfate in 5 percent $n$-butanol at $25^{\circ} \mathrm{C} \ldots \ldots . . .20$

12. Experimental values of relative apparent molar enthalpies, $L_{\phi}$, for sodium dodecyl sulfate in 5 percent $i$-propanol at $20^{\circ} \mathrm{C} \ldots \ldots . .$.

13. Experimental values of relative apparent molar enthalpies, $L_{\phi}$, for sodium dodecyl sulfate in 5 percent $i$-propanol at $30^{\circ} \mathrm{C} \ldots . . .$.

14. Experimental values of apparent molar enthalpies, $\mathrm{H}_{6}$, for sodium dodecyl sulfate in $0.0858 \mathrm{~m} \mathrm{NaCl}$ at $30^{\circ} \mathrm{C} \ldots \ldots \ldots \ldots$

15. Experimental values of apparent molar enthalpies, $\mathrm{H}_{\varnothing}$, for sodium dodecyl sulfate in $0.17158 \mathrm{~m} \mathrm{NaCl}$ at $30^{\circ} \mathrm{C} \ldots \ldots \ldots \ldots$

16. Critical micelle concentrations for sodium dodecyl sulfate ........ 25

17. Selected values for sodium dodecyl sulfate ................. 25 


\title{
THERMODYNAMICS OF AQUEOUS SODIUM DODECYL SULFATE
}

\author{
by
}

Robert L. Berg 1

\begin{abstract}
A flow microcalorimeter system has been assembled and is being used in a thermodynamic study of surfactant systems as part of the Energy Research and Development Administration's enhanced oil recovery program. Enthalpies of dilution and demicellization of sodium dodecyl sulfate have been measured over a temperature range of $20^{\circ}$ to $35^{\circ} \mathrm{C}$. This surfactant has also been studied with cosurfactant and salt backgrounds. The critical micelle concentrations $(\mathrm{cmc})$ have been determined and are in excellent agreement with those in the literature: Studies below the $\mathrm{cmc}$ suggest the possible formation of a dimer. Work on alkyl sulfonates and alkylbenzene sulfonates is planned.
\end{abstract}

\section{INTRODUCTION}

The development of a successful micellar-polymer oil recovery program is dependent on supporting research which will allow oilfield flooding to be carried out with an optimal utilization of chemicals to produce significant quantities of residual oil. The process of micellar flooding has been described in the literature $(\underline{6}, 14) .{ }^{2}$ At present, still unanswered are numerous fundamental questions concerning the stability of micellar systems with temperature

1 Research chemist.

2 Underlined numbers in parentheses refer to ifems in the list of references at the end of this report. 
and pressure, with brine background, cosurfactant, and hydrocarbons. The purpose of this continuing study of the thermodynamics of oil recovery surfactant systems is to answer the questions: What is the structure of a micelle? What is the mechanism of micelle formation? and What causes the special properties of micellar systems?

Thermodynamics is a valuable tool for the understanding of the reactions occurring between micellar systems and oil-reservoir fluids in oilfield flooding. By the use of calorimetry, it is possible to determine the strength of the interactions between micelles and brine systems and to give additional information to the petroleum engineer about the stability of micellar solutions: The effect of a cosurfactant on micellar structure is still largely conjecture; yet the blending of surfactant and cosurfactant is one of the few parameters which can be controlled in micellar flooding. Knowledge of the thermodynamic interactions of surfactant and cosurfactant would be of great value in the planning of oil recovery processes. Earlier thermodynamic studies of surfactants show wide discrepancies both in terms of experimental results and of theoretical interpretation.

The intent of this thermodynamic research is to obtain an understanding of micellar interactions to allow more knowledgeable planning of oilfield recovery processes.

This report describes the strategy and apparatus being used in the experimental thermodynamic study of micellar systems and presents the results of measurements on a simple well-defined surfactant system. This initial study of a simple surfactant system does not answer the questions mentioned above; however, considerable information about micelle behavior already has been obtained in the course of this investigation. The work has also raised additional questions concerning micelle structure such as the extent of premicellar association and the nature of solubilization effects.

The surfactant chosen for this initial study was sodium dodecyl sulfate, $\mathrm{NaC}_{1}$ a $\mathrm{H}_{25} \mathrm{SO}_{4}$. Although sodium dodecyl sulfate shows little promise as an oilfield chemical, its physical and chemical properties have been extensively studied. Mukerjee and Mysels (16), in their 1966 tabulation of critical micelle concentrations (cmc), list more than 600 measurements of the $\mathrm{cmc}$ by more than 50 methods. Since 1966, additional work has appeared including thermodynamic measurements and calculations. Because of this extensive study, sodium dodecyl sulfate served as a test surfactant for this initial calorimetric study.

Various background conditions were used which demonstrate the ability of thermodynamic measurements to provide information concerning the effect of salt and cosurfactant backgrounds on micellar behavior. Calorimetric measurements of enthalpies of dilution and demicellization are reported for sodium dodecyl sulfate in: 
water at $20^{\circ}, 25^{\circ}, 30^{\circ}$, and $35^{\circ} \mathrm{C}$,

$0.01 \mathrm{~m}$ and $0.001 \mathrm{~m} \mathrm{NaCl}$ at $20^{\circ}$ and $30^{\circ} \mathrm{C}$,

$0.17158 \mathrm{~m}$ ( 1 percent) and $0.0858 \mathrm{~m}\left(0.5\right.$ percent) $\mathrm{NaCl}$ at $30^{\circ} \mathrm{C}$,

5 percent $n$-butanol at $20^{\circ}$ and $25^{\circ} \mathrm{C}$, and

5 percent $\mathrm{i}$-propanol at $20^{\circ}$ and $30^{\circ} \mathrm{C}$.

\section{EXPERIMENTAL}

\section{Strategy}

A measurable heat effect occurs when a solution of micellar material is diluted. This heat effect (enthalpy change) results from the change of the structure of the solution due to dilution and demicellization. The magnitude of these heat changes is small, and their significance is not in the temperature change that a surfactant slug would experience on dilution, but rather these effects give a measure of the stability of the micellar material in thermodynamic terms. The aggregation of the long-chain surfactant ions in solution to form micelles is a reaction which increases rapidly over a narrow concentration range (the critical micelle concentration). Nearly all measured properties of micellar solutions show an abrupt change in this concentration region. The calorimetric measurements of heat effects were also expected to show this change in solution structure. The strategy adopted for the calorimetric studies was to determine dilution enthalpies above and below the critical micelle concentration $(\mathrm{cmc})$. Construction of a curve showing the interrelationship of each of the measured dilutions allows calculation of the heat-of-micelle formation. For each dilution, the measured heat effect is given by equation 1,

$$
\Delta H \text { (measured })=H_{\phi}(\text { final })-H_{\phi}(\text { initial }),
$$

where the $\mathrm{H}_{\varnothing}$ are apparent molar enthalpies.

For solutions with electrolyte background, the observed reaction may be written as:

$$
\begin{gathered}
\mathrm{NaC}_{12} \mathrm{H}_{25} \mathrm{SO}_{4} \cdot r\left(\mathrm{NaX} \cdot \mathrm{nH}_{2} \mathrm{O}\right)+x\left(\mathrm{NaX} \cdot \mathrm{nH}_{2} \mathrm{O}\right)= \\
\mathrm{NaC}_{12} \mathrm{H}_{25} \mathrm{SO}_{4} \cdot(r+x)\left(\mathrm{NaX} \cdot n \mathrm{H}_{2} \mathrm{O}\right)
\end{gathered}
$$

where $\mathrm{NaX}$ is the electrolyte. The reaction of interest, the change of enthalpy for the sodium dodecyl sulfate, 


$$
\begin{gathered}
\mathrm{NaC}_{12} \mathrm{H}_{25} \mathrm{SO}_{4} \cdot r\left(n \mathrm{H}_{2} \mathrm{O}\right)+x\left(\mathrm{nH}_{2} \mathrm{O}\right)= \\
\mathrm{NaC}_{22} \mathrm{H}_{25} \mathrm{SO}_{4} \cdot(r+x)\left(n \mathrm{H}_{2} \mathrm{O}\right)
\end{gathered}
$$

does not include the dilution enthalpy terms for the salt background. Therefore "correction" terms for the dilution of the electrolyte are subtracted from the measured heat change to give the reaction of equation 3 . The correction equations are

$$
\begin{gathered}
r\left(\mathrm{NaX} \cdot \infty \mathrm{H}_{2} \mathrm{O}\right)=r\left(\mathrm{NaX} \cdot \mathrm{nH}_{2} \mathrm{O}\right) \\
x\left(\mathrm{NaX} \cdot \infty \mathrm{H}_{2} \mathrm{O}\right)=x\left(\mathrm{NaX} \cdot \mathrm{nH}_{2} \mathrm{O}\right) \\
(r+x)\left(\mathrm{NaX} \cdot n \mathrm{H}_{2} \mathrm{O}\right)=(r+x)\left(\mathrm{NaX} \cdot \infty \mathrm{H}_{2} \mathrm{O}\right) .
\end{gathered}
$$

The values for reactions 4 through 6 were taken from the literature $(13,21)$ and are largely compensatory. The sum of the correction terms is generally less than $4 \mathrm{cal} \mathrm{mol}^{-1}$. The enthalpy change for equation 3 is given by

$$
\Delta H=\Delta H(\text { measured })+\Sigma
$$

where $\Sigma$ is the sum of the correction terms arising from the dilution of the electrolyte.

No corrections have been made for the measurements in alcohol backgrounds. To make such corrections requires enthalpy-of-unmixing data for the alcohol at constant molality as a function of background ionic strength. It would be necessary to assume a model for the background electrolyte and to measure mixing enthalpies for the alcohol and the model electrolyte. The author believes these quantities would be small and largely compensatory as in the salt background case.

For any solution,

$$
H_{\phi}=H_{\phi}^{\circ}+L_{\varnothing},
$$

where $L_{\varnothing}$ is the relative apparent molar enthalpy and $\mathrm{H}_{\phi}{ }^{\circ}$ is the apparent molar enthalpy of the reference state of infinite dilution. The use of equation 8 to give $L_{\varnothing}$ values is essentially a scaling operation to give $L_{\phi}$ at zero concentration a value of zero. 
For convenience in assembling and interrelating the $\Delta \mathrm{H}$ terms, $\mathrm{H}_{\phi}$ for an initial stock solution was arbitrarily assigned a value of zero, and a segment of the curve of $\mathrm{H}_{\phi}$ versus molality was constructed into which other series of values were fitted by interpolation and scaling. A value for $\mathrm{H}_{\phi}{ }^{\circ}$ was determined by extrapolation of measurements below the $\mathrm{cmc}$ to infinite dilution using a plot of $H_{\phi}$ versus $m^{\frac{1}{2}}$. Equations, such as the Debye-Huckel equations $(\underline{9}, 19)$, were also used for fitting the data below the cmc.

The general equation for the calorimeter process is

$$
\Delta H(\text { measured })=\epsilon \times S / n,
$$

where $\epsilon$ is a calibration constant, $S$ the measured signal, and $n$ the amount of material diluted. The convention of giving a negative sign to the enthalpy change for an exothermal reaction is followed throughout this work. Throughout this report $1 \mathrm{cal}=4.184 \mathrm{~J}$.

\section{Apparatus}

The experimental measurements were performed with a commercial microcalorimeter (LKB) ${ }^{3}$ which is operated as a heat-conduction flow instrument (15). The calorimeter system is shown in figure 1. A baseline steady state is established by pumping water through both injection pumps. The reaction is initiated by introducing reactant through one of the pumps into the mixing zone of the flow cell.

A steady-state heat effect is maintained as long as the pumping rates and ratio are constant. A change in the pump ratio gives a different final concentration and, therefore, a different heat effect. The heat effect measured is the heat transfer across the surrounding thermopiles. The calibration constant for the instrument was determined by passing a measured electrical current through a 50 -ohm heater mounted in the base of the mixing cell. The calibration constant is considered accurate to 0.5 percent.

3 Reference to specific brand of equipment is made for identification only and does not imply endorsement by ERDA. 


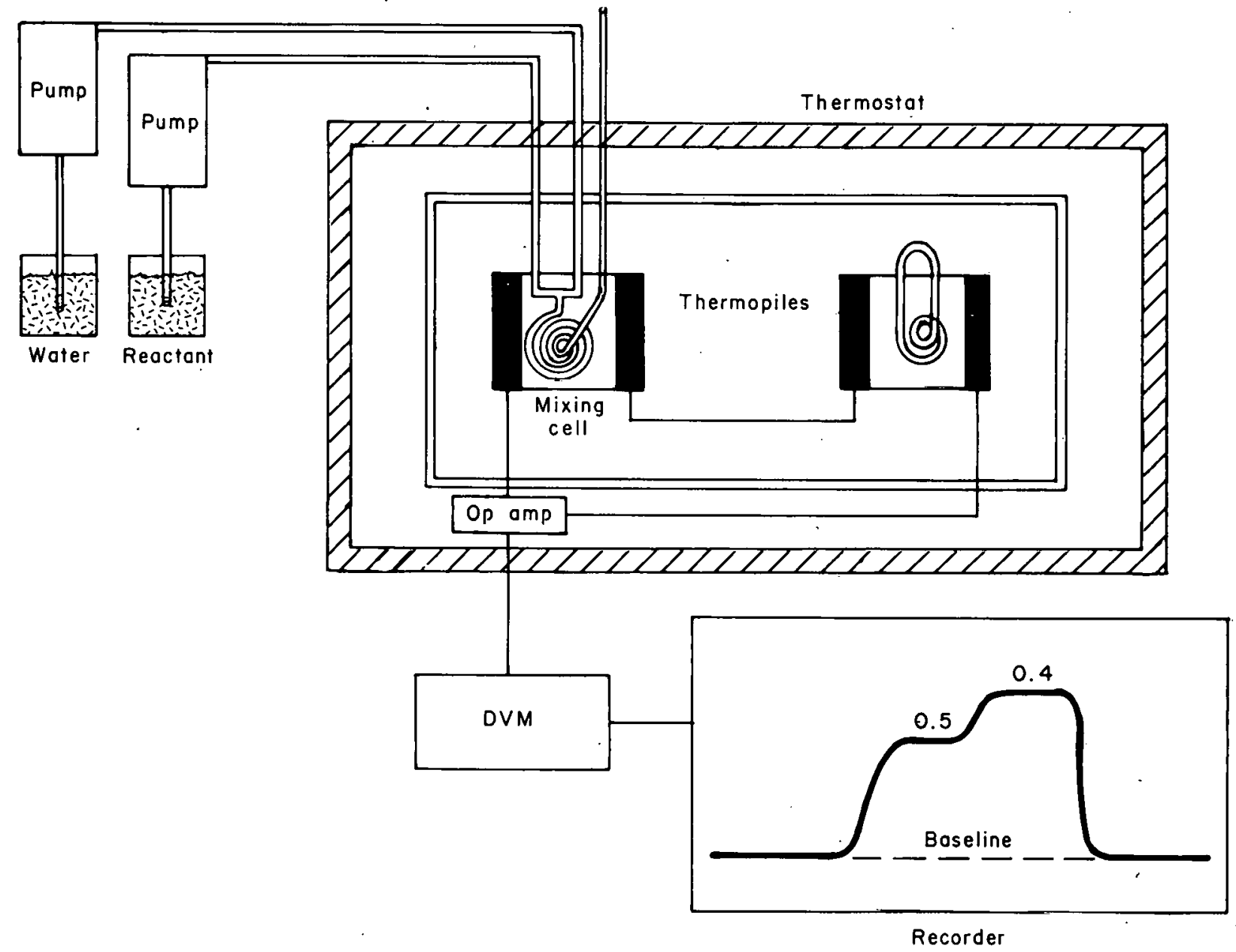

FIGURE 1. Flow Microcalorimeter System.

Several modifications were made on the commercial instrument. The calorimeter block was placed within a "submarine;" of the type designed by R. Biltonen (11), in a Tronac water bath with a Tronac-40 temperature controller. The water bath provides a more stable thermal environment for the calorimeter. A platinum resistance thermometer placed inside the submarine indicated a stability of better than $0.0005^{\circ} \mathrm{C}$. The thermal environment of the calorimeter cells should be of even greater temperature stability. The resistance thermometer, 
calibrated at the National Bureau of Standards, was also used to determine the absolute temperature of the calorimeter. Measurements were carried out at $20^{\circ}$, $25^{\circ}, 30^{\circ}$, and $35^{\circ} \mathrm{C} \pm 0.005^{\circ} \mathrm{C}$.

Initial measurements with sodium dodecyl sulfate using the LKB peristaltic pumps with silicone tubing indicated an adsorption of the surfactant on the silicone creating a concentration gradient. This problem was avoided by use of the Picker design (23) all-Teflon axial rotary piston pump. These pumps give stable flow ratcs and very little pulsation. The pumps were calibrated by measuring the mass of water pumped in a given time period. The molar flow rates were calculated by use of density values obtained from interpolation of measured densities. The scanning mode was not used with the pumps, but the programed steps for flow ratios have been used extensively in this work. The overall flow rate for the work reported here was approximately $0.5 \mathrm{~cm}^{3} \mathrm{~min}^{-1}$. Entering solutions were thermostated in an external heat exchanger consisting of several coils of gold tubing within the submarine before they were allowed to enter the internal heat exchangers of the calorimeter block. Use of water temperature $10^{\circ}$ to $15^{\circ} \mathrm{C}$ different from the bath temperature gave no deflection of the baseline. This would indicate that the thermostating by the heat exchangers of incoming solutions to calorimeter temperature is complete.

The detection system consists of two pairs of thermopiles wired in opposition. For the $25^{\circ}$ and $35^{\circ} \mathrm{C}$ measurements, the thermopile output was sent into a Keithley 150B microvolt amplifier. The amplifier analog output was directed to a strip chart recorder.

For the $20^{\circ}$ and $30^{\circ} \mathrm{C}$ measurements, a major modification of the amplifier system was made. An operational amplifier was mounted on the wall of the calorimeter block, and the output from the operational amplifier was sent to a Dana 5000 digital voltmeter, then to a recorder and to an interface for data handling and storage in a digital form. The use of the operational

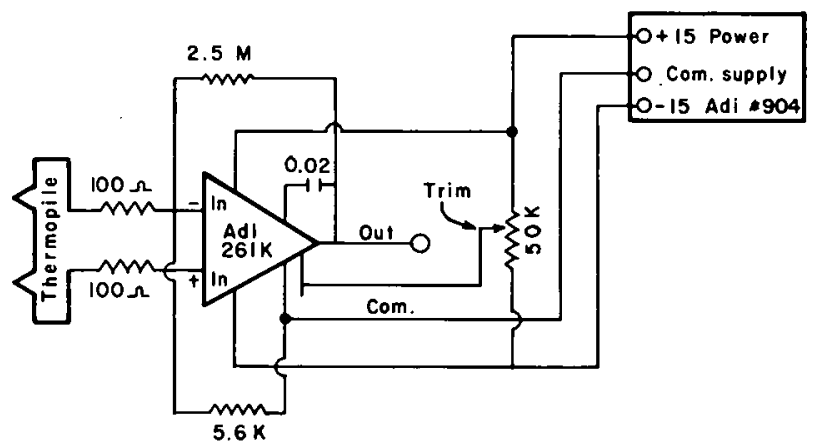

FIGURE 2. Modified Amplification System. amplifier circuit shown in figure 2 gives a gain of approximately 25,000 . This gives increased sensitivity with reduced noise since the signal coming out of the calorimeter to the digital voltmeter has a magnitude of volts or millivolts rather than the microvolt or nanovolt signal with the original system. The operational amplifier is a Analog Devices module, 261K, which has an extremely low 
temperature drift, less than U.I microvolt per degree, which is not observed at the stability level of the water bath, This amplification system is of the type in use on microcalorimeters designed by $:$. J. Prosen at the National Bureau of Standards (24).

For the $20^{\circ} \mathrm{C}$ measurements, an additional modification was made on the instrument. The flow-through cell, shown on! the right-hand side of the calorimeter in figure 1, was replaced with a second mixing cell. A set of paired pumps was used on that side of the calorimeter, thereby canceling some viscosity heating effects between the two calorimeter cells and giving a more stable baseline.

The calorimeter performance was checked with sodium chloride solutions and with sucrose solutions. The measured enthalpy changes were in excellent agreement with the literature values $(7,21)$. The minimum detectable signal with the modified instrument is approximately 0.2 microwatt and reproducibility is 0.2 percent. It is believed that by use of a statistical treatment of the digital output greater reproducibility may be obtained.

\section{Materials}

The sodium dodecyl sulfate was prepared by E. J. Eisenbraun of Oklahoma State University, who used a modification of the procedure of Dreger (2). The starting material was commercial dodecanoic acid. The acid was esterified with diazomethane, and the resulting ester was fractionally distilled through a 1 -inch by 14-inch packed column containing perforated 1/4-inch steel saddles. A Teflon spinning band column was also tried, but it was found that the results were comparable. Gas chromatographic analysis using a Carbowax $20 \mathrm{M}$ column, 1/4 inch by 10 feet, showed the ester to be free of impurities. It was then reduced with diisobutylaluminum hydride in toluene. The resulting alcohol was distilled and then treated with chlorosulfonic acid to give the half ester. The half ester was neutralized to the sodium salt using the calculated amount of sodium carbonate. It was filtered, recrystallized repeatedly from isopropyl alcohol, filtered again, and then dried overnight at reduced pressure $(0.2 \mathrm{~mm} \mathrm{Hg})$ at $100^{\circ} \mathrm{C}$.

Elemental analysis gave the following results (with the theoretical values in parentheses): carbon, 49.99 (49.98); hydrogen, 8.58 (8.74); sulfur, 10.92 (11.12); and sodium, $8.02(7.97)$. The observed critical micelle concentrations from the enthalpy measurements are in excellent agreement with those reported in the literature (16) and indicate a high purity for the sample.

All measurements on a solution were made the same day that the solution was prepared since early experiments showed a change in enthalpy values after 24 hours. This change is believed to result from the reported hydrolysis of the 
dodecyl sulfate (10). Any surface water was removed by drying by pumping at room temperature (pressure less than $2 \times 10^{-3} \mathrm{~mm} \mathrm{Hg}$ ) for at least 3 hours. All solutions were made with water distilled from alkaline permanganate solution and were prepared on a mass basis with appropriate corrections for buoyancy. The water was boiled shortly before use in order to remove any dissolved gases which would cause bubbles in the pumping system or calorimeter cells.

The sodium chloride solutions were prepared from Fisher Certified Reagent, Lot 753783 , which was dried at $100^{\circ} \mathrm{C}$ for 4 hours or longer before use. The sodium bromide solutions were prepared from Fisher Certified Reagent, Lot 764930 , dried at $110^{\circ} \mathrm{C}$ for 4 hours before use. Isopropanol solutions were prepared from Fisher Certified A.C.S., Lot 754537, 2-propanol, and n-butanol solutions from Fisher Certified A.C.S., Lot 751188, 1-butanol. Concentrations of all solution prepared for use as background media are considered accurate to at least 0.1 percent.

\section{RESULTS}

Tables 1 through 13 present the experimentally determined enthalpies for the dilution of sodium dodecyl sulfate at the conditions listed. In all cases, at least one additional non-significant figure is carried in the tabulated terms to avoid rounding errors. The $L_{\phi}$ terms are based on equation 8 where at infinite dilution the $L_{\phi}$ is assigned the value of zero. Tables 14 and 15 include experimental enthalpies for dilutions in higher sodium chloride concentration. A 1-percent $\mathrm{NaCl}$ solution corresponds to $0.17158 \mathrm{~m}$ and 0.5 percent to $0.0858 \mathrm{~m}$. Measurements below the cmc have not been made owing to the extremely low concentration, so the $\mathrm{H}_{\varnothing}$ terms are not referenced to the infinitely dilute state but only to a convenient reference point. These dilution measurements are of interest in demonstrating the change in shape of the dilution curve with increasing salt concentration. Values for the $\mathrm{cmc}$ at various background conditions are given in table 16 . Smoothed values for the $L_{\phi}$ terms in water at selected molalities are given in table 17. A graphical presentation of the results is given in figures 3 through 9. A dilution which occurs endothermally corresponds to an increase on the ordinate. 
TABLE 1. Experimental values of relative apparent molar enthalpies, $L$, $\phi$, for sodium dodecyl sulfate in $\mathrm{H}_{2} \mathrm{O}$ at $20^{\circ} \mathrm{C}$

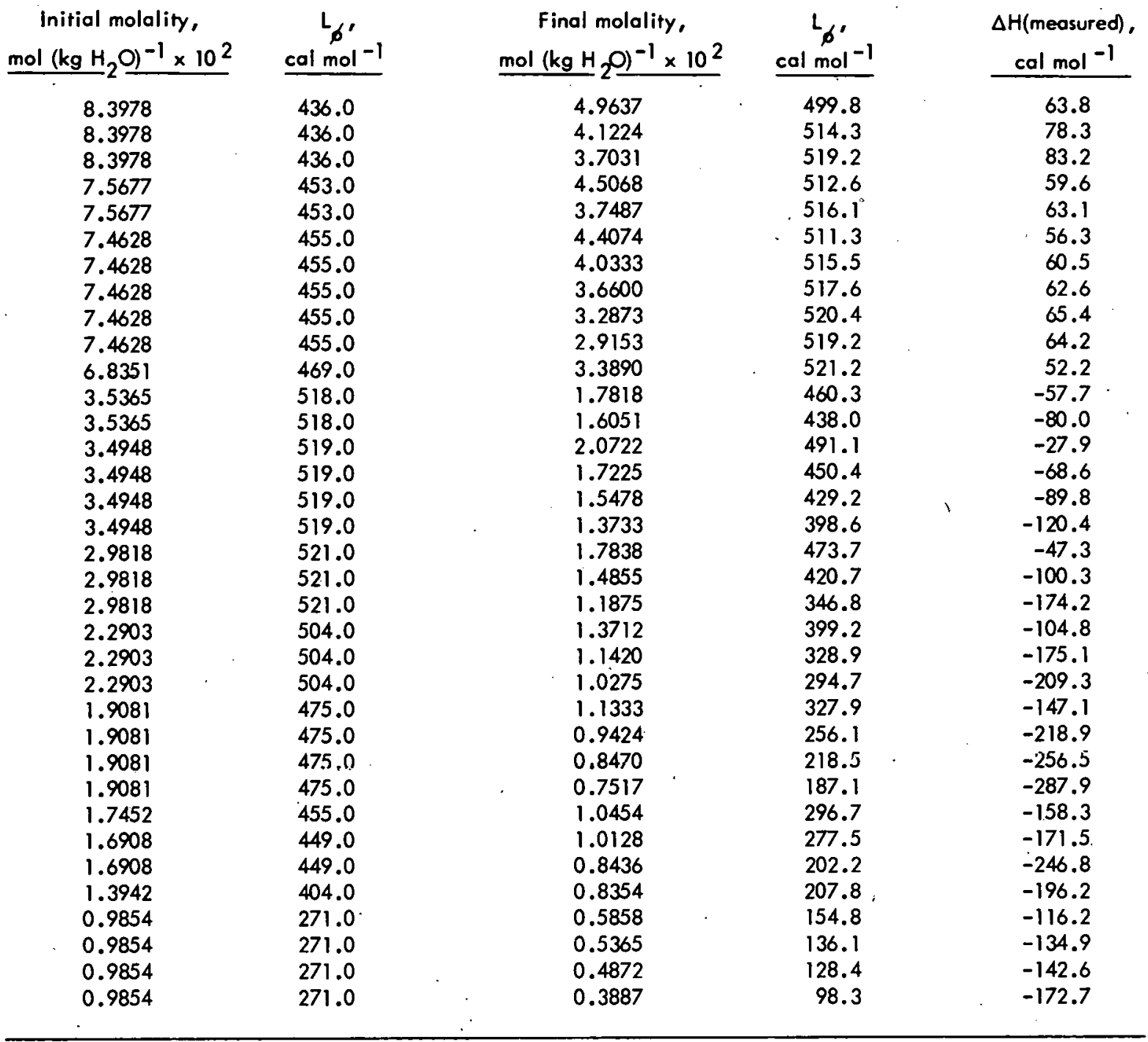


TABLE 2. Experimental values of relative apparent molar enthalpies, $L_{\varnothing}$, for sodium dodecyl sulfate in $\mathrm{H}_{2} \mathrm{O}$ at $25^{\circ} \mathrm{C}$

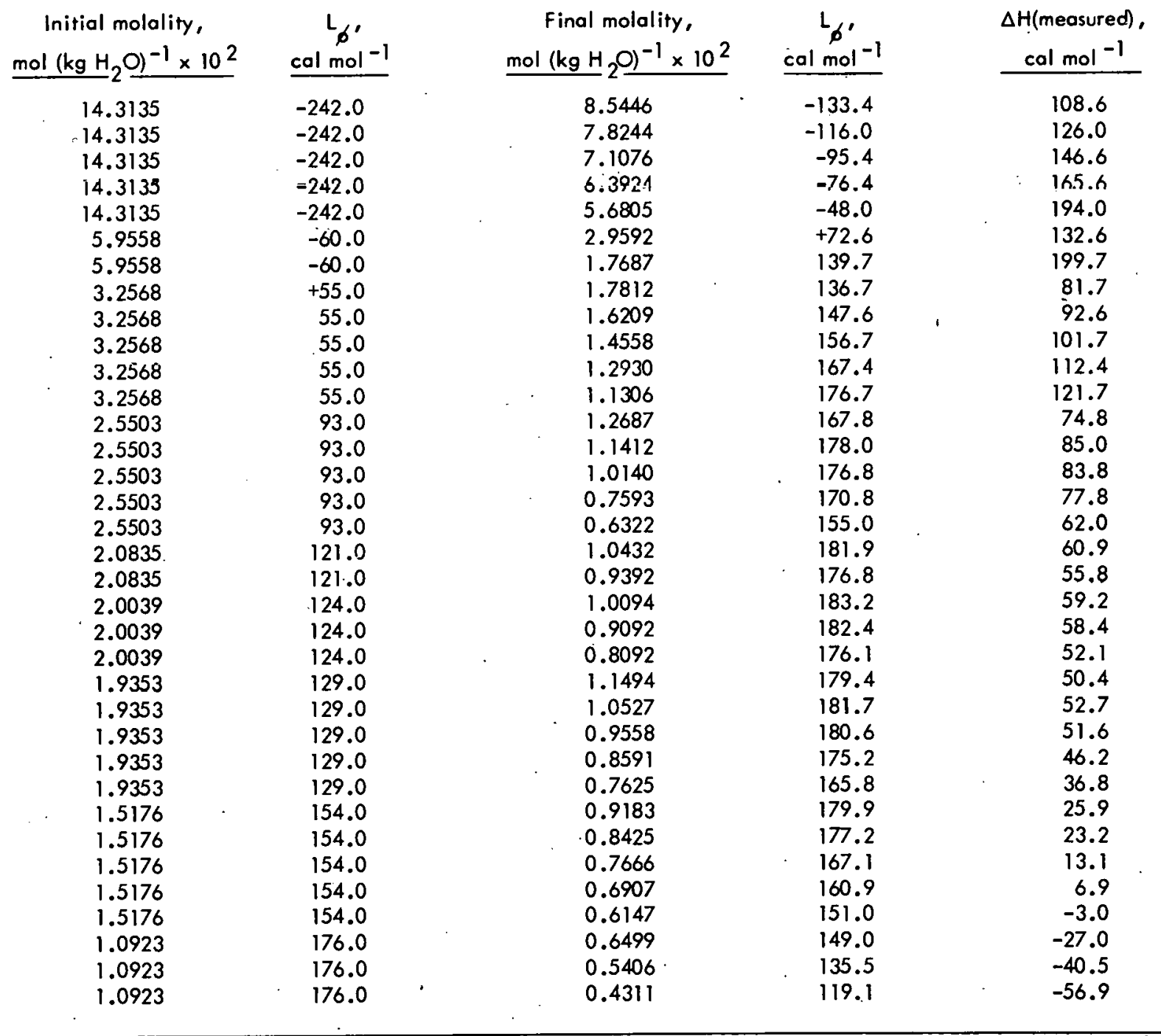


TABLE 3. Experimental values of relative apparent molar enthalpies, $L \phi$, for sodium dodecyl sulfate in $\mathrm{H}_{2} \mathrm{O}$ at $30^{\circ} \mathrm{C}$

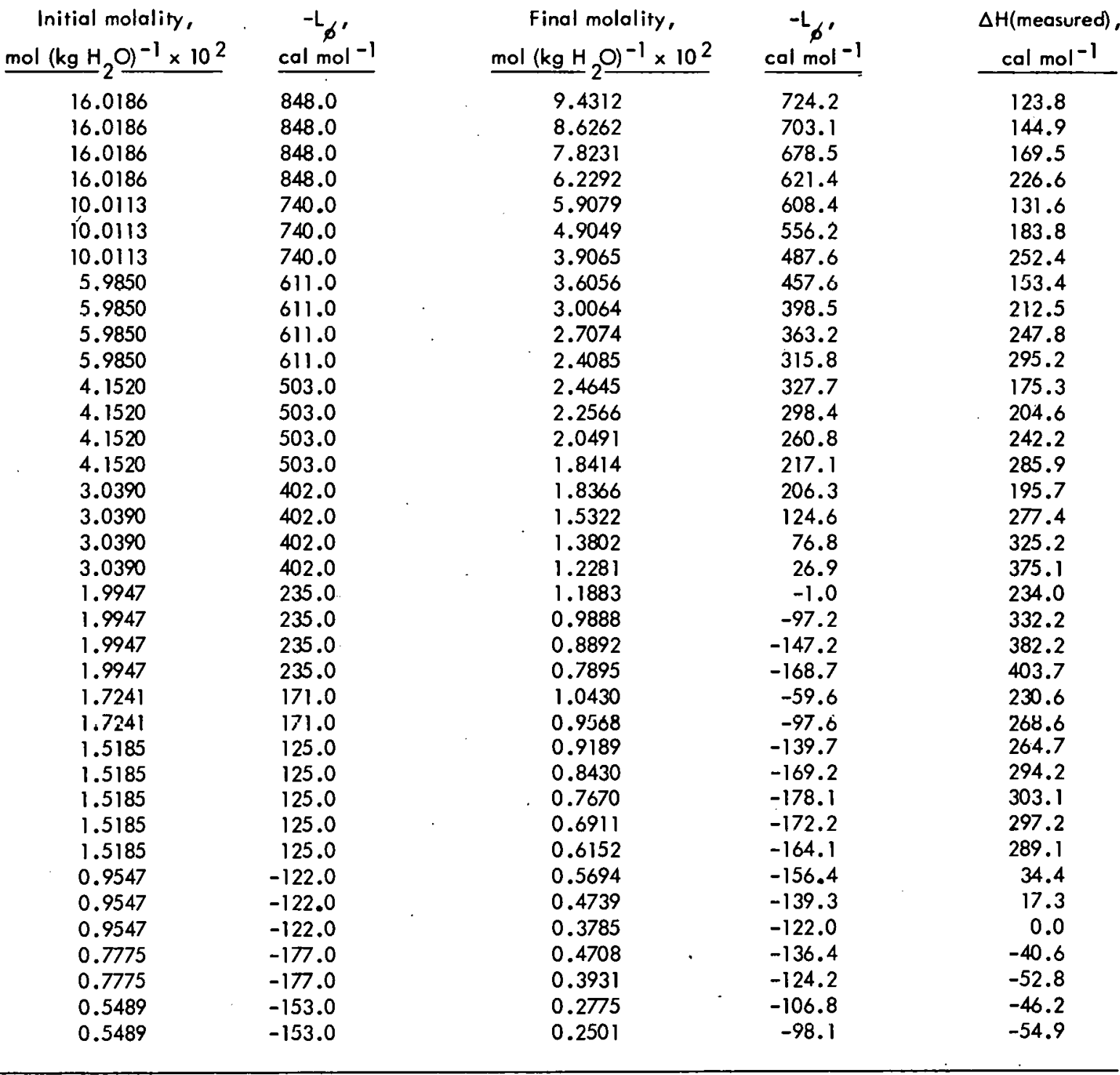


TABLE 4. Experimental values of relative apparent molar enthalpies, $L$, for sodium dodecyl sulfate in $\mathrm{H}_{2} \mathrm{O}$ at $35^{\circ} \mathrm{C}$

\begin{tabular}{|c|c|c|c|c|}
\hline 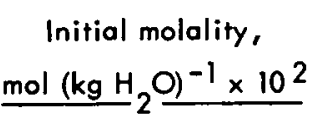 & $\begin{array}{r}-\mathrm{L}_{6}^{\prime} \\
\mathrm{cal} \mathrm{mol}-1 \\
\end{array}$ & $\begin{array}{l}\text { Final molality, } \\
\mathrm{mol}\left(\mathrm{kg} \mathrm{H} 2^{\mathrm{O}}\right)^{-1} \times 10^{2} \\
\end{array}$ & $\begin{array}{c}-L_{6} \\
\text { cal mol }-1 \\
\end{array}$ & $\begin{array}{c}\Delta H \text { (measured), } \\
\mathrm{cal} \mathrm{mol}^{-1} \\
\end{array}$ \\
\hline 17.4625 & 1422.0 & 10.3733 & 1287.1 & 134.9 \\
\hline 17.4625 & 1422.0 & 8.6200 & 1236.4 & 185.6 \\
\hline 17.4625 & 1422.0 & 6.8807 & 1167.0 & 255.0 \\
\hline 7,5743 & 1196.0 & 4.5112 & 1012.8 & 183.2 \\
\hline 7.5743 & 1196.0 & 3.7825 & 936.8 & 259.2 \\
\hline 7.5743 & 1196.0 & 3.0262 & 828.6 & 367.4 \\
\hline 4.5478 & 1013.0 & 2.7233 & 772.5 & 240.5 \\
\hline 4.5478 & 1013.0 & 2.5064 & 723.8 & 289.2 \\
\hline 4.5478 & 1013.0 & 2.2795 & 662.7 & 350.3 \\
\hline 4.5478 & 1013.0 & 1.8256 & 517.0 & 496.0 \\
\hline 2.1332 & 613.0 & 1.2752 & 205.7 & 407.3 \\
\hline 2.1332 & 613.0 & 1.0618 & 36.3 & 576.7 \\
\hline 2.1332 & 613.0 & 0.8485 & -186.1 & 799.1 \\
\hline 1.6057 & 402.0 & 0.9602 & -77.0 & 479.0 \\
\hline 1.6057 & 402.0 & 0.8799 & -154.2 & 556.2 \\
\hline 1.6057 & 402.0 & 0.7996 & -197.4 & 599.4 \\
\hline 1.6057 & 402.0 & 0.7193 & -183.8 & 585.8 \\
\hline 1.6057 & 402.0 & 0.6392 & -177.0 & 579.0 \\
\hline 1.1059 & 83.0 & 0.6616 & -179.3 & 262.3 \\
\hline 1.1059 & 83.0 & 0.5510 & -163.5 & $246.5^{\circ}$ \\
\hline 1.1059 & 83.0 & 0.4404 & -144.2 & 227.2 \\
\hline 0.8185 & -197.0 & 0.4941 & -153.9 & -43.1 \\
\hline 0.8185 & -197.0 & 0.4122 & -143.2 & -53.8 \\
\hline 0.7434 & -189.0 & 0.4451 & -149.0 & -40.0 \\
\hline 0.7434 & -189.0 & 0.3706 & -131.3 & -57.7 \\
\hline
\end{tabular}


TABLE 5. Experimental values of relative apparent molar enthalpies, $L 6$, for sodium dodecyl sulfate in $0.001 \mathrm{~m} \mathrm{NaCl}$ at $20^{\circ} \mathrm{C}$

\begin{tabular}{|c|c|c|c|c|c|}
\hline $\begin{array}{l}\text { Initial molality, } \\
\text { mol }\left(\mathrm{kg} \mathrm{H}_{2} \mathrm{O}^{-1} \times \mathrm{i0}^{2}\right. \\
\end{array}$ & $\begin{array}{c}\mathrm{L}_{6}{ }^{\prime} \\
\mathrm{cal} \mathrm{mol}^{-1} \\
\end{array}$ & $\begin{array}{c}\text { Final molality, } \\
\text { mol }\left(\mathrm{kg} \mathrm{H}_{2} \mathrm{O}\right)^{-1} \times 10^{2}\end{array}$ & $\begin{array}{c}\mathrm{L}_{\phi} \\
\mathrm{cal} \mathrm{mol}^{-1} \\
\end{array}$ & $\begin{array}{l}\Delta H \text { (measured), } \\
\mathrm{cal} \mathrm{mol}-1 \\
\end{array}$ & $\begin{array}{c}-\Sigma, \\
\mathrm{col} \mathrm{mol} \\
\end{array}$ \\
\hline $\begin{array}{l}5.7825 \\
5.7825\end{array}$ & 523.0 & & 556.5 & $\begin{array}{l}-33.9 \\
-205\end{array}$ & $\begin{array}{l}0.4 \\
0.5\end{array}$ \\
\hline $\begin{array}{l}5.7825 \\
5.7825\end{array}$ & $\begin{array}{l}523.0 \\
523.0\end{array}$ & $\begin{array}{l}2.8419 \\
2.2646\end{array}$ & $\begin{array}{l}553.0 \\
539.2\end{array}$ & $\begin{array}{l}-30.5 \\
-16.9\end{array}$ & $\begin{array}{l}0.5 \\
0.7\end{array}$ \\
\hline 2.9442 & 555.0 & 1.7467 & 503.5 & +51.0 & 0.5 \\
\hline 2.9442 & 555.0 & 1.4521 & 453.5 & 100.9 & 0.6 \\
\hline 2.9442 & 555.0 & 1.3049 & 424.2 & .130 .0 & 0.8 \\
\hline 2.9442 & 555.0 & 1.1579 & 384.5 & 169.6 & 0.9 \\
\hline 2.9370 & 552.0 & 1.7513 & 510.8 & 40.7 & 0.5 \\
\hline 2.9370 & 552.0 & 1.4574 & 453.6 & 97.8 & 0.6 \\
\hline 2.9370 & 552.0 & 1.3106 & 431.1 & 120.2 & 0.7 \\
\hline 2.9370 & 552.0 & 1.1639 & 387.3 & 163.8 & 0.9 \\
\hline 1.8731 & 519.0 & 1.1125 & 360.8 & 157.7 & 0.5 \\
\hline 1.8731 & 519.0 & 0.9251 & 267.7 & 250.6 & 0.7 \\
\hline 1.8731 & 519.0 & 0.8315 & 218.5 & 299.7 & 0.8 \\
\hline 1.8731 & 519.0 & 0.7379 & 173.3 & 344.7 & 1.0 \\
\hline 1.1407 & 382.0 & 0.6780 & 171.2 & 210.2 & 0.6 \\
\hline 1.1407 & 382.0 & 0.5639 & 141.4 & 239.8 & 0.8 \\
\hline 1.1407 & 382.0 & 0.5069 & 119.5 & 261.6 & 0.9 \\
\hline 1.1407 & 382.0 & 0.4499 & 103.7 & 277.3 & 1.0 \\
\hline 0.7717 & 202.0 & 0.3453 & 85.0 & 116.1 & 0.9 \\
\hline 0.7717 & 202.0 & 0.3068 & 65.5 & 135.5 & 1.0 \\
\hline
\end{tabular}


TABLE 6. Experimental values of relative apparent molar enthalpies, $L \phi$, for sodium dodecyl sulfate in $0.01 \mathrm{~m} \mathrm{NaCl}$ at $20^{\circ} \mathrm{C}$

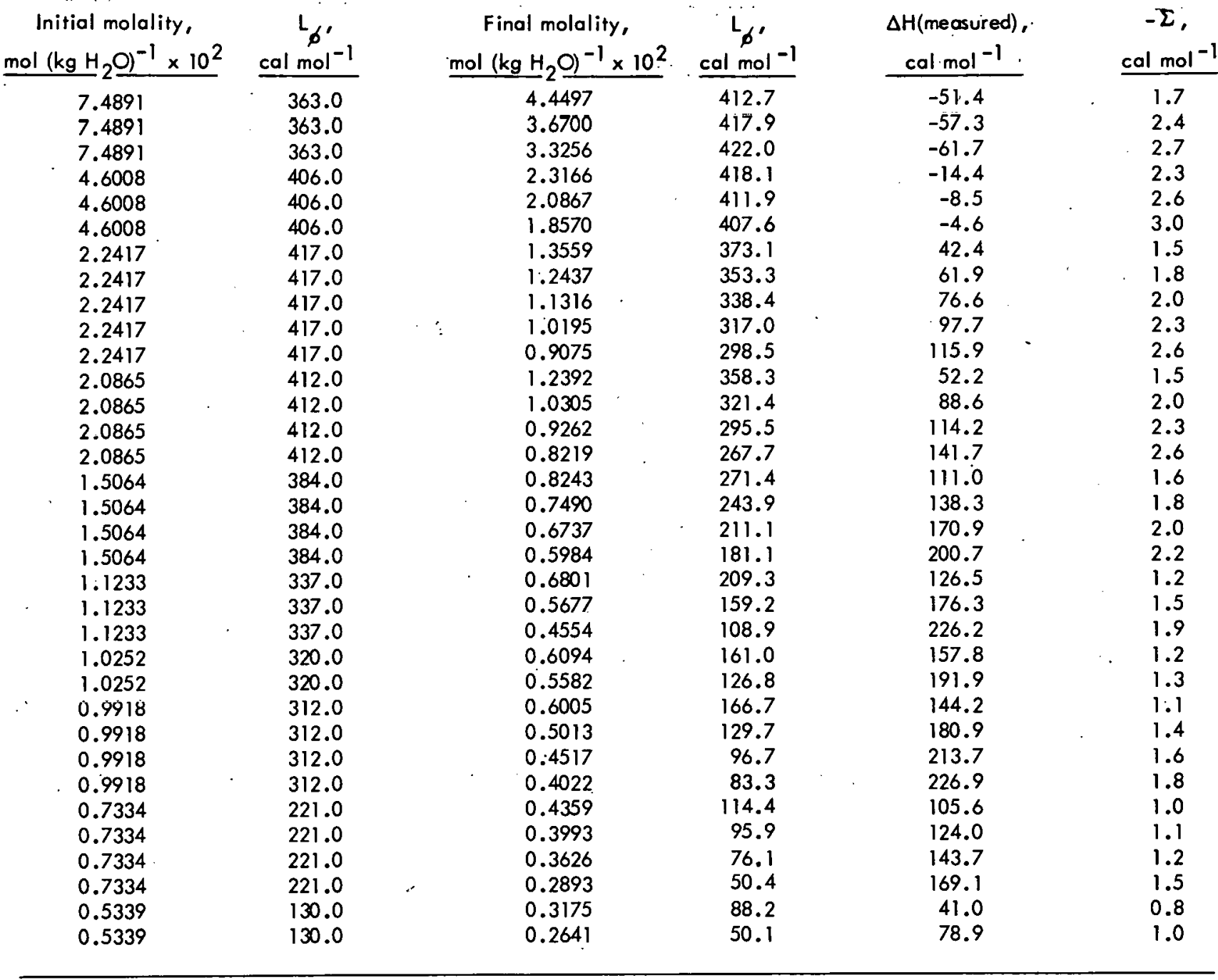


TABLE 7. Experimental values of relative apparent molar enthalpies, $L_{\phi}$, for sodium dodecyl sulfate in $0.001 \mathrm{~m} \mathrm{NaCl}$ at $30^{\circ} \mathrm{C}$.

\begin{tabular}{|c|c|c|c|c|c|}
\hline $\begin{array}{l}\text { Initial molality, } \\
\text { nol }\left(\mathrm{kg} \mathrm{H}_{2} \mathrm{O}^{-1} \times 10^{2}\right.\end{array}$ & $\begin{array}{c}-\mathrm{L}_{\mathrm{o}} \\
\mathrm{cal} \mathrm{mol}-1 \\
\end{array}$ & $\begin{array}{l}\text { Final molality, } \\
\mathrm{mol}(\mathrm{kg} \mathrm{H} \\
\end{array}$ & $\begin{array}{c}\mathrm{L}_{6} \\
\text { cal mol-1 } \\
\end{array}$ & $\begin{array}{c}\Delta H \text { (measured), } \\
\text { cal mol }^{-1} \\
\end{array}$ & $\begin{array}{c}-\Sigma, \\
\mathrm{cal} \mathrm{mol}-1 \\
\end{array}$ \\
\hline $\begin{array}{l}8.1913 \\
8.1913 \\
8.1913 \\
8.1913 \\
5.7949 \\
5.7949 \\
3.9501 \\
3.9501 \\
3.9501 \\
3.9501 \\
3.4245 \\
3.4245 \\
1.8480 \\
1.8480 \\
1.6932 \\
1.6932 \\
1.6932 \\
1.6932 \\
1.5214 \\
1.5214 \\
1.4280 \\
1.4280 \\
1.4280 \\
1.4280 \\
1.4280 \\
1.4280\end{array}$ & $\begin{array}{r}608.0 \\
608.0 \\
608.0 \\
608.0 \\
522.0 \\
522.0 \\
419.0 \\
419.0 \\
419.0 \\
419.0 \\
378.0 \\
378.0 \\
165.0 \\
165.0 \\
134.0 \\
134.0 \\
134.0 \\
134.0 \\
86.0 \\
86.0 \\
67.0 \\
67.0 \\
67.0 \\
67.0 \\
67.0 \\
67.0\end{array}$ & $\begin{array}{l}4.9330 \\
4.1121 \\
3.2944 \\
2.8868 \\
2.9173 \\
2.3389 \\
2.3886 \\
1.9932 \\
1.5985 \\
1.4014 \\
1.7291 \\
1.3869 \\
1.1197 \\
0.9349 \\
1.0262 \\
0.9415 \\
0.8568 \\
0.6875 \\
0.7700 \\
0.6179 \\
0.8651 \\
0.7937 \\
0.7228 \\
0.6514 \\
0.5801 \\
0.5087\end{array}$ & $\begin{array}{r}-479.5 \\
-430.0 \\
-367.2 \\
-326.9 \\
-329.1 \\
-252.7 \\
-262.3 \\
-193.3 \\
-108.5 \\
-60.2 \\
-135.2 \\
-41.3 \\
+54.6 \\
140.4 \\
93.2 \\
130.6 \\
173.3 \\
218.0 \\
201.1 \\
196.0 \\
175.1 \\
192.2 \\
214.0 \\
209.1 \\
192.2 \\
190.6\end{array}$ & $\begin{array}{l}128.9 \\
178.6 \\
241.7 \\
282.1 \\
193.6 \\
270.2 \\
157.2 \\
226.4 \\
311.4 \\
359.9 \\
243.5 \\
337.6 \\
220.2 \\
306.2 \\
227.7 \\
265.2 \\
308.0 \\
352.9 \\
287.7 \\
282.8 \\
242.6 \\
259.8 \\
281.7 \\
276.8 \\
260.1 \\
258.6\end{array}$ & $\begin{array}{l}0.4 \\
0.6 \\
0.9 \\
1.0 \\
0.7 \\
0.9 \\
0.5 \\
0.7 \\
0.9 \\
1.1 \\
0.7 \\
0.9 \\
0.6 \\
0.8 \\
0.5 \\
0.6 \\
0.7 \\
0.9 \\
0.6 \\
0.8 \\
0.5 \\
0.6 \\
0.7 \\
0.7 \\
0.9 \\
1.0\end{array}$ \\
\hline
\end{tabular}


TABLE 8. Experimental values of relative apparent molar enthalpies, $L_{\varnothing}$ for sodium dodecyl sulfate in $0.01 \mathrm{~m} \mathrm{NaCl}$ at $30^{\circ} \mathrm{C}$

\begin{tabular}{|c|c|c|c|c|c|}
\hline $\begin{array}{c}\text { Initial molality, } \\
\text { mol }\left(\mathrm{kg} \mathrm{H}_{2} \mathrm{O}\right)^{-1} \times 10^{2} \\
\end{array}$ & $\begin{array}{c}-\mathrm{L}_{6}^{\prime} \\
\mathrm{cal} \mathrm{mol}^{-1} \\
\end{array}$ & $\begin{array}{l}\text { Final molality, } \\
\text { mol }\left(\mathrm{kg} \mathrm{H}_{2} \mathrm{O}\right)^{-1} \times 10^{2}\end{array}$ & $\begin{array}{c}-\mathrm{L}_{6^{\prime}} \\
\text { cal mol }-1 \\
\end{array}$ & $\begin{array}{l}\Delta H \text { (measured), } \\
\mathrm{cal} \mathrm{mol}^{-1} \\
\end{array}$ & $\begin{array}{l}-\Sigma, \\
\text { cal mol-1 } \\
\end{array}$ \\
\hline 8.6855 & 740.0 & 5.6178 & 663.2 & 78.5 & 1.7 \\
\hline 8.6855 & 740.0 & 5.1815 & 647.0 & 95.0 & 2.0 \\
\hline 8.6855 & 740.0 & 4.3114 & 612.2 & 130.5 & 2.7 \\
\hline 7.3724 & 717.0 & 4.3436 & 613.8 & 105.3 & 2.1 \\
\hline 7.3724 & 717.0 & 3.9742 & 593.9 & 125.5 & 2.4 \\
\hline 7.3724 & 717.0 & 3.6053 & 575.2 & 144.6 & 2.8 \\
\hline 7.3724 & 717.0 & 3.2372 & 552.0 & 168.3 & 3.3 \\
\hline 7.3724 & 717.0 & 2.8696 & 522.7 & 198.0 & 3.7 \\
\hline 4.3008 & 613.0 & 2.5408 & 495.0 & 120.1 & 2.1 \\
\hline 4.3008 & 613.0 & 2.1104 & 444.7 & 171.1 & 2.8 \\
\hline 4.3008 & 613.0 & 1.6808 & 378.1 & 238.5 & 3.6 \\
\hline 3.1180 & 544.0 & 1.8687 & 408.3 & 137.6 & 1.9 \\
\hline 3.1180 & 544.0 & 1.5568 & 347.5 & 199.1 & 2.6 \\
\hline 3.1180 & 544.0 & 1.4008 & 315.3 & 231.6 & 2.9 \\
\hline 3.1 .180 & 544.0 & 1.2451 & 267.3 & 280.0 & 3.3 \\
\hline 2.6733 & 507.0 & 1.6858 & 375.7 & 133.0 & 1.7 \\
\hline 2.6733 & 507.0 & 1.4183 & 319.6 & 189.7 & 2.3 \\
\hline 2.6733 & 507.0 & 1.1511 & 238.2 & 271.8 & 3.0 \\
\hline 1.5779 & 358.0 & 0.9344 & 155.3 & 204.4 & 1.7 \\
\hline 1.5779 & 358.0 & 0.8554 & 109.0 & 250.9 & 1.9 \\
\hline 1.5779 & 358.0 & 0.7765 & 73.0 & 287.1 & 2.1 \\
\hline 1.5779 & 358.0 & 0.6976 & 19.5 & 340.9 & 2.4 \\
\hline 1.5779 & 358.0 & 0.6188 & -30.0 & 390.7 & 2.7 \\
\hline 1.2051 & 257.0 & 0.7235 & +31.1 & 227.3 & 1.4 \\
\hline 1.2051 & 257.0 & 0.6030 & -48.8 & 307.7 & 1.9 \\
\hline 1.2051 & 257.0 & 0.4825 & -102.5 & 361.8 & 2.3 \\
\hline 1.2051 & 257.0 & 0.4223 & -102.1 & 361.7 & 2.6 \\
\hline 1.2051 & 257.0 & 0.3621 & -88.7 & 348.5 & 2.8 \\
\hline 1.0409 & 203.0 & 0.5209 & -67.6 & 272.3 & 1.7 \\
\hline 1.0409 & 203.0 & 0.4689 & -99.9 & 304.8 & 1.9 \\
\hline 1.0409 & 203.0 & 0.4169 & -100.1 & 305.3 & 2.2 \\
\hline 1.0409 & 203.0 & 0.3648 & -110.5 & 315.9 & 2.4 \\
\hline
\end{tabular}


TABLE 9. Experimental values of relative apparent molar enthalpies, $L$ for sodium dodecyl sulfate in $0.01 \mathrm{~m} \mathrm{NaBr}$ at $30^{\circ} \mathrm{C}$

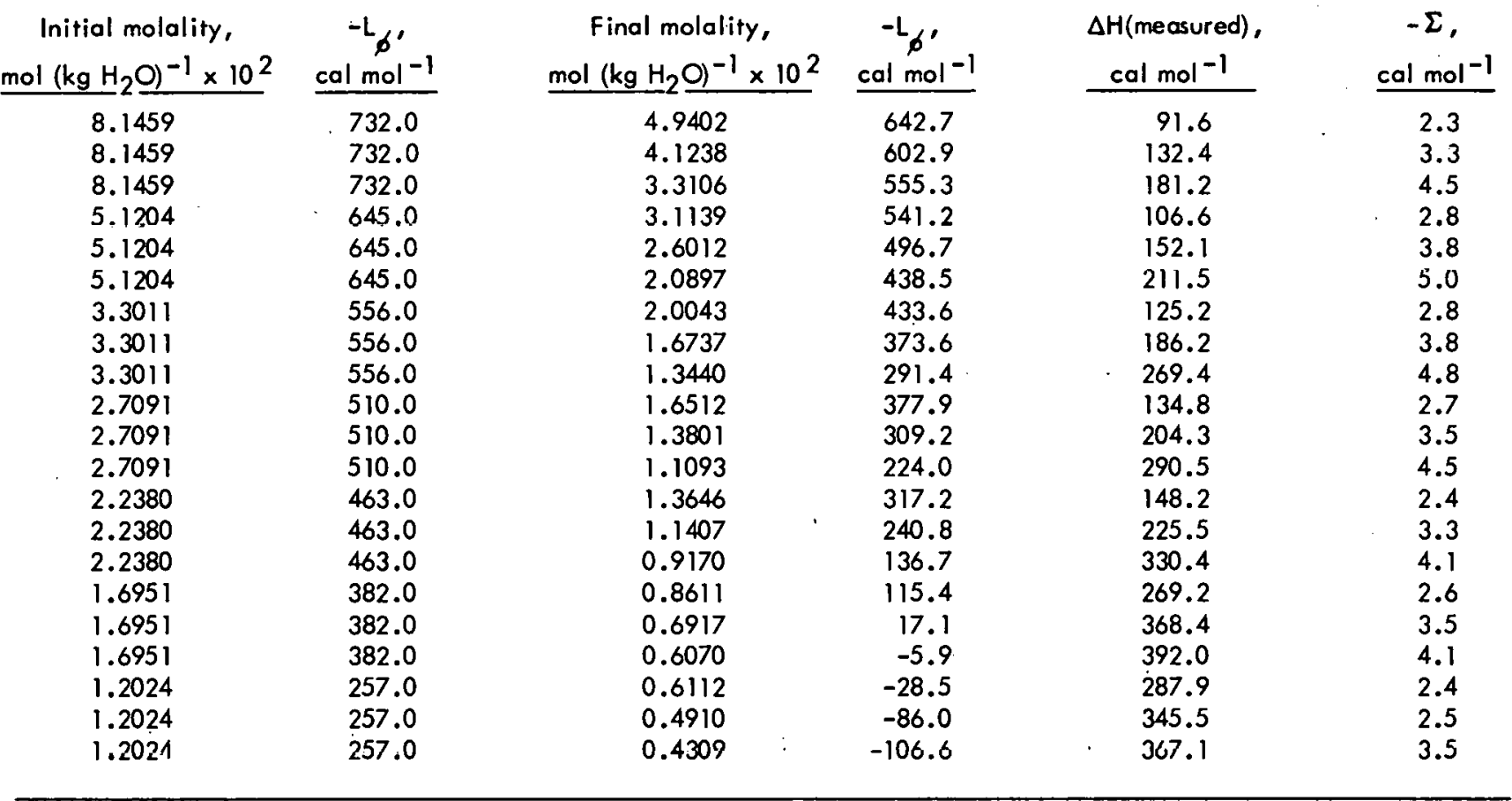


TABLE 10. Experimental values of relative apparent molar enthalpies, $L \phi$, for sodium dodecyl sulfate in 5 percent n-butanol at $20^{\circ} \mathrm{C}$

\begin{tabular}{|c|c|c|c|c|}
\hline $\begin{array}{c}\text { Initial molality, } \\
\text { mol }\left(\mathrm{kg} \mathrm{H}_{2} \mathrm{O}\right)^{-1} \times 10^{2}\end{array}$ & $\begin{array}{c}-L_{\sigma^{\prime}} \\
\text { cal mol } \\
\end{array}$ & $\begin{array}{c}\text { Final molality, } \\
\mathrm{mol}\left(\mathrm{kg} \mathrm{H} \mathrm{O}^{-1} \times 10^{2}\right.\end{array}$ & $\begin{array}{c}-L_{b^{\prime}} \\
\mathrm{col} \mathrm{mol}^{-1}\end{array}$ & $\begin{array}{c}\Delta H \text { (measured), } \\
\mathrm{rnl} \mathrm{mnl} \mathrm{l}^{-1} \\
\end{array}$ \\
\hline 6.8692 & 3330.0 & 4.1540 & 2471.2 & 858.8 \\
\hline 6.8692 & 3330.0 & 3.4664 & 2181.9 & 1148.1 \\
\hline 6.8692 & 3330.0 & 3.1230 & 2045.3 & 1284.7 \\
\hline 6.8692 & 3330.0 & 2.7800 & 1849.5 & 1480.5 \\
\hline 2.8245 & 1884.0 & 1.7117 & 1089.6 & 794.4 \\
\hline 2.8245 & 1884.0 & 1.4292 & 862.6 & 1021.4 \\
\hline 2.8245 & 1884.0 & 1.1468 & 588.7 & 1295.3 \\
\hline 2.2322 & 1500.0 & 1.3533 & 779.6 & 720.4 \\
\hline 2.2322 & 1500.0 & 1.1300 & 558.0 & 942.0 \\
\hline 2.2322 & 1500.0 & 1.0184 & 451.9 & . 1048.1 \\
\hline 2.2322 & 1500.0 & 0.9068 & 314.7 & 1185.3 \\
\hline 1.0412 & 515.0 & 0.6316 & -3.0 & 518.0 \\
\hline 1.0412 & 515.0 & 0.5275 & -123.3 & 638.3 \\
\hline 1.0412 & 515.0 & 0.4754 & -187.3 & 702.3 \\
\hline 1.0412 & 515.0 & 0.4234 & -259.0 & 774.0 \\
\hline 0.8726 & 240.0 & 0.5294 & -172.9 & 412.9 \\
\hline 0.8726 & 240.0 & 0.4421 & -249.5 & 489.5 \\
\hline 0.8726 & 240.0 & 0.3985 & -295.3 & 535.3 \\
\hline 0.8726 & 240.0 & 0.3549 & -321.8 & 561.8 \\
\hline 0.4851 & -170.0 & 0.2944 & -270.8 & 100.8 \\
\hline 0.4851 & -170.0 & 0.2459 & -225.3 & 55.3 \\
\hline 0.4851 & -170.0 & 0.2216 & -170.0 & 0.0 \\
\hline
\end{tabular}


TABLE 11. Experimental values of relative apparent molar enthalpies, $L \varnothing$, for sodium dodecyl sulfate in 5 percent $n$-butanol at $25^{\circ} \mathrm{C}$

\begin{tabular}{|c|c|c|c|c|}
\hline $\begin{array}{c}\text { Initial molality, } \\
\mathrm{mol}^{\prime}\left(\mathrm{kg} \mathrm{H}_{2} \mathrm{O}\right)^{-1} \times 10^{2}\end{array}$ & $\begin{array}{c}-L_{6^{\prime}} \\
\text { cal mol }-1 \\
\end{array}$ & $\begin{array}{c}\text { Final molality, } \\
\text { mol }(\mathrm{kg} \mathrm{H}, 0)^{-1} \times 10^{2} \\
\end{array}$ & $\begin{array}{c}-L_{\phi \prime} \\
\text { cal mol } \\
\end{array}$ & $\begin{array}{c}\Delta H(\text { measured }), \\
\mathrm{cal} \mathrm{mol}^{-1} \\
\end{array}$ \\
\hline 7.3073 & 3757.0 & 4.1035 & 2850.2 & 906.8 \\
\hline 7.3073 & 3757.0 & 3.7379 & 2712.2 & 1044.8 \\
\hline 7.3073 & 3757.0 & 3.3726 & 2571.1 & 1185.9 \\
\hline 7.3073 & 3757.0 & 3.0077 & 2389.8 & 1367.2 \\
\hline 6.2772 & 3528.0 & 3.8352 & 2756.3 & 771.7 \\
\hline 6.2772 & 3528.0 & 3.2068 & 2500.1 & 1027.9 \\
\hline 6.2772 & 3528.0 & 2.5795 & 2185.6 & 1342.4 \\
\hline 5.7031 & 3408.0 & 3.4855 & 2615.4 & 792.6 \\
\hline 5.7031 & 3408.0 & 2.9146 & 2363.2 & 1044.8 \\
\hline 5.7031 & 3408.0 & 2.3447 & 2018.4 & 1389.6 \\
\hline 2.5006 & 2124.0 & 1.5308 & 1395.3 & 728.7 \\
\hline 2.5006 & 2124.0 & 1.4057 & 1262.8 & 861.2 \\
\hline 2.5006 & 2124.0 & 1.2807 & 1170.5 & 953.5 \\
\hline 2.5006 & 2124.0 & 1.0307 & 880.0 & 1244.0 \\
\hline 1.4246 & 1300.0 & 0.8726 & 679.8 & 620.2 \\
\hline 1.4246 & 1300.0 & 0.7301 & 487.4 & 812.6 \\
\hline 1.4246 & 1300.0 & 0.5877 & 294.6 & 1005.4 \\
\hline 1.3387 & 1218.0 & 0.8200 & 592.7 & 625.3 \\
\hline 1.3387 & 1218.0 & 0.6861 & 438.4 & 779.6 \\
\hline 1.3387 & 1218.0 & 0.5523 & $201: 0$ & 1017.0 \\
\hline 1.1210 & 990.0 & 0.6868 & 440.2 & 549.8 \\
\hline 1.1210 & 990.0 & 0.6307 & 363.4 & 626.6 \\
\hline 1.1210 & 990.0 & 0.5747 & 295.7 & 694.3 \\
\hline 1.1210 & 990.0 & 0.5186 & 207.4 & 782.6 \\
\hline 1.1210 & 990.0 & 0.4626 & 77.8 & 912.2 \\
\hline 0.9845 & 822.0 & 0.6032 & 306.8 & 515.2 \\
\hline 0.9845 & 822.0 & 0.5540 & 225.0 & 597.0 \\
\hline 0.9845 & 822.0 & 0.5048 & 166.8 & 655.2 \\
\hline 0.9845 & 822.0 & 0.4555 & 96.1 & 725.9 \\
\hline 0.9845 & 822.0 & 0.4063 & -6.9 & 828.9 \\
\hline 0.4541 & 80.0 & 0.2783 & -171.4 & 251.4 \\
\hline 0.4541 & 80.0 & 0.2556 & -184.1 & 264.1 \\
\hline 0.4541 & 80.0 & 0.2329 & -209.8 & 289.8 \\
\hline 0.4541 & 80.0 & 0.2102 & -207.6 & 287.6 \\
\hline 0.4541 & 80.0 & 0.1875 & -173.6 & 253.6 \\
\hline
\end{tabular}


TABLE 12. Experimental values of relative apparent molar enthalpies, $L, \phi$ ' for sodium dodecyl sulfate in 5 percent i-propanol at $20^{\circ} \mathrm{C}$

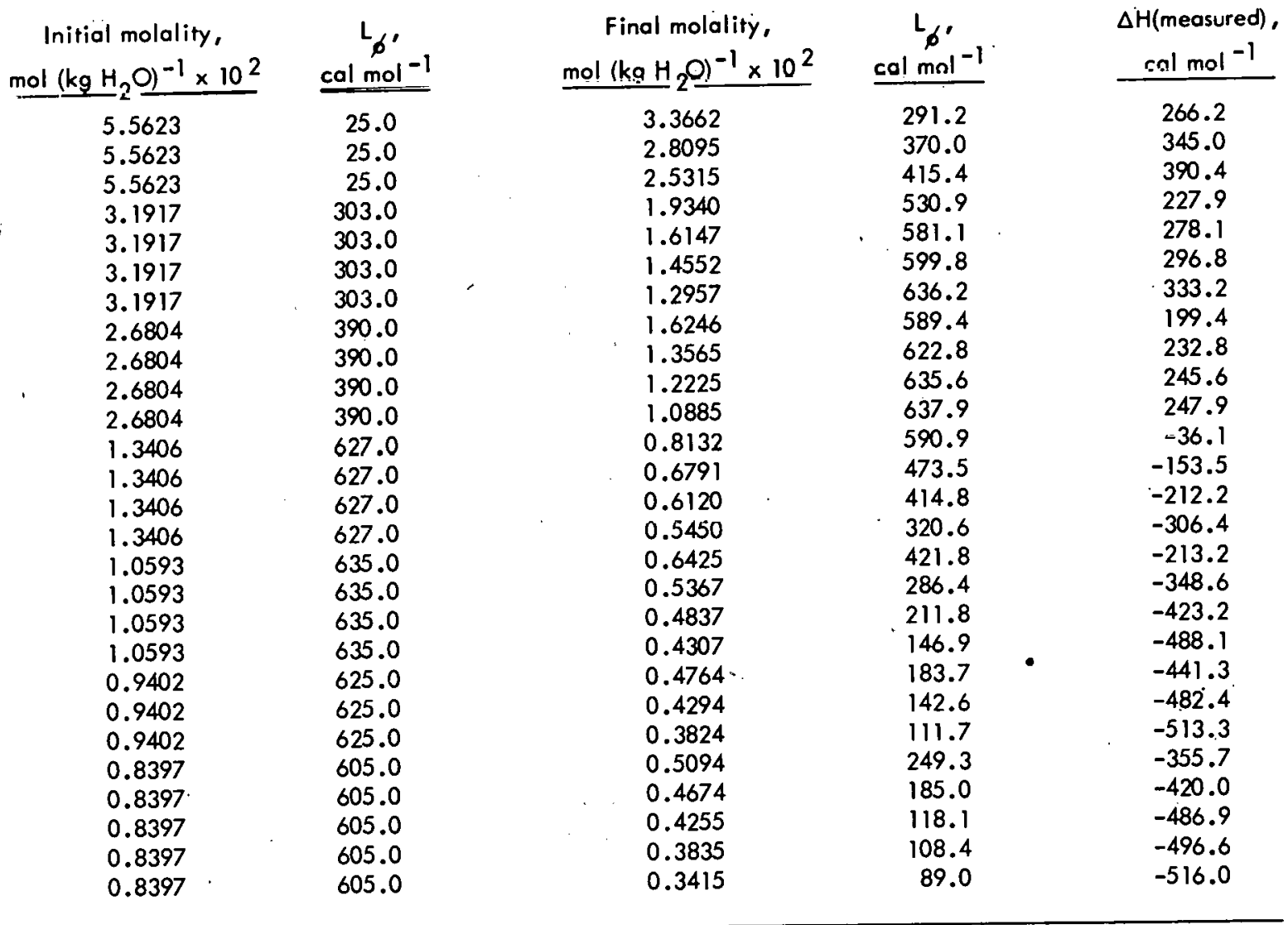


TABLE 13. Experimental values of relative apparent molar enthalpies, $L$, for sodium dodecyl sulfate in 5 percent i-propanol at $30^{\circ} \mathrm{C}$

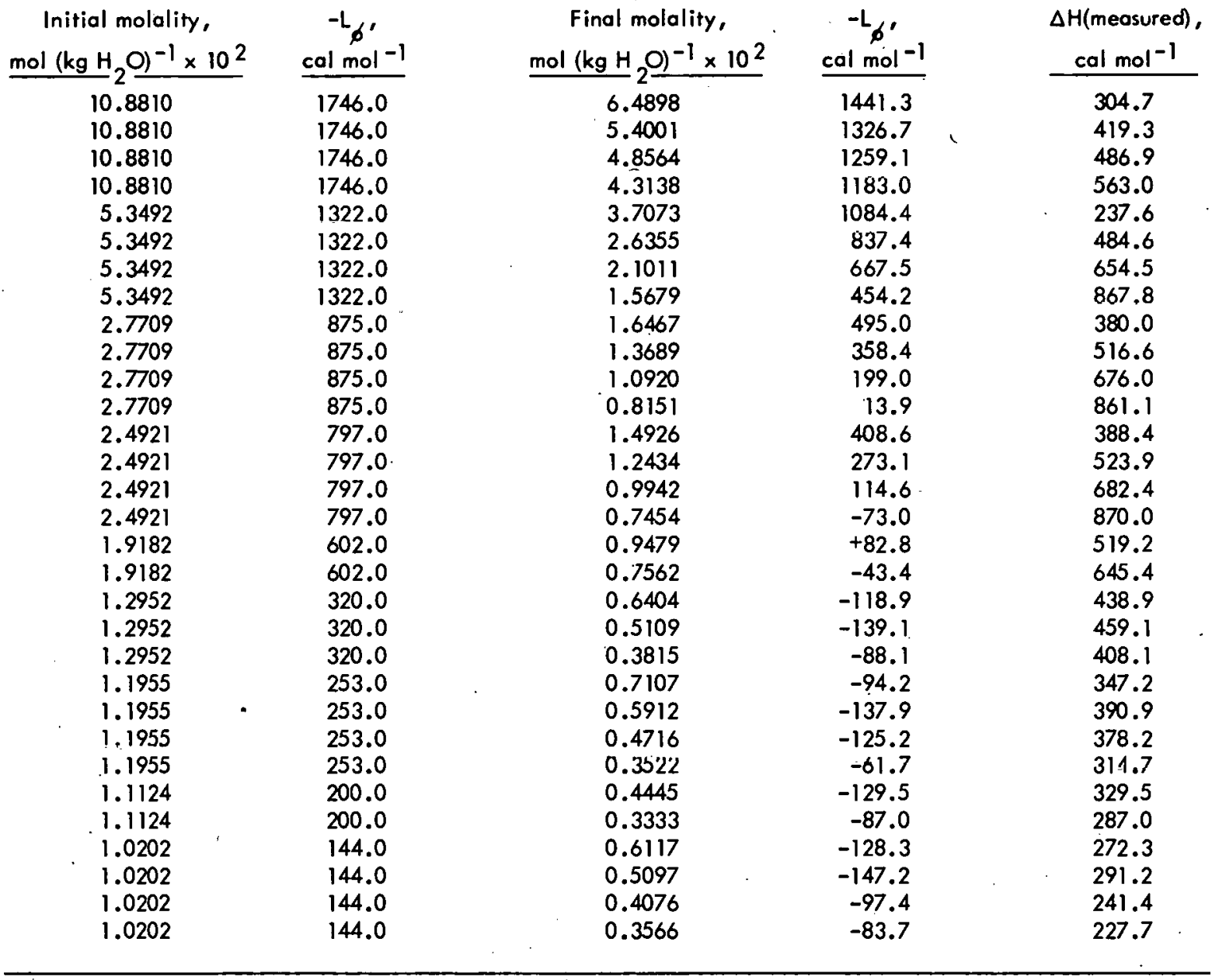


TABLE 14. Experimental values of apparent mol'ar enthalpies, $H$ sodium dodecyl sulfate in $0.0858 \mathrm{~m} \mathrm{NaCl}$ at $30^{\circ} \mathrm{C}$

\begin{tabular}{|c|c|c|c|c|c|}
\hline $\begin{array}{c}\text { Initial molality, } \\
\text { mol }\left(\mathrm{kg} \mathrm{H}, \mathrm{O}^{-1} \times 10^{2}\right.\end{array}$ & $\begin{array}{c}-\mathrm{H}_{\mathrm{f}^{\prime}} \\
\text { cal mol }-1 \\
\end{array}$ & $\begin{array}{l}\text { Final molality, } \\
\text { mol }(\mathrm{kg} \mathrm{H} \\
\end{array}$ & $\begin{array}{c}-\dot{H}_{6^{\prime}} \\
\mathrm{cal} \mathrm{mol}^{-1} \\
\end{array}$ & $\begin{array}{l}\Delta H \text { (measured), } \\
\mathrm{cal} \mathrm{mol}^{-1} \\
\end{array}$ & $\begin{array}{c}-\Sigma, \\
\mathrm{cal} \mathrm{mol}-1 \\
\end{array}$ \\
\hline 11.0138 & 493.0 & 7.1261 & 459.4 & 36.7 & 3.1 \\
\hline 11.0138 & 493.0 & 6.5723 & $452 . ?$ & 44.4 & 3.6 \\
\hline 11.0138 & 493.0 & 5.4687 & 436.2 & 61.5 & 4.7 \\
\hline 11.0138 & 493.0 & 4.3696 & 413.9 & 85.0 & 5.9 \\
\hline 6.4875 & 450.0 & 3.8723 & 399.7 & 53.1 & 2.8 \\
\hline 6.4875 & 450.0 & 3.2227 & 379.4 & 74.2 & 3.6 \\
\hline 6.4875 & 450.0 & 2.5749 & 355.0 & 99.5 & 4.5 \\
\hline 6.4875 & 450.0 & 1.9286 & 321.2 & 134.2 & 5.4 \\
\hline 5.3764 & 434.0 & 3.2498 & 387.3 & 49.2 & 2.5 \\
\hline 5.3764 & 434.0 & 2.7116 & 368.0 & 69.2 & 3.2 \\
\hline 5.3764 & 434.0 & 2.1745 & 342.3 & 95.6 & 3.9 \\
\hline 3.4225 & 390.0 & 2.0545 & 331.9 & 59.9 & 1.8 \\
\hline 3.4225 & 390.0 & 1.7121 & 304.7 & 87.6 & 2.3 \\
\hline 3.4225 & 390.0 & 1.3701 & 268.6 & 124.3 & 2.9 \\
\hline 3.4225 & 390.0 & 1.1993 & 240.1 & 153.0 & 3.1 \\
\hline 3.2604 & 387.0 & 1.6248 & 307.4 & 81.9 & 2.3 \\
\hline 3.2604 & 387.0 & 1.2989 & 271.2 & 118.6 & 2.8 \\
\hline 2.4005 & 349.0 & 1.4375 & 278.4 & 72.0 & 1.4 \\
\hline 2.4005 & 349.0 & 1.1974 & 247.5 & 103.3 & 1.8 \\
\hline 2.4005 & 349.0 & 0.9574 & 210.9 & 140.3 & 2.2 \\
\hline 1.5992 & 290.0 & 0.9551 & 196.5 & 94.5 & 1.0 \\
\hline 1.5992 & 290.0 & 0.7951 & 154.3 & 137.0 & 1.3 \\
\hline 1.2080 & 255.0 & 0.7217 & 147.2 & 108.6 & 0.8 \\
\hline 1.2080 & 255.0 & 0.6008 & 99.8 & 156.2 & 1.0 \\
\hline 1.2080 & 255.0 & 0.4801 & 23.9 & 232.3 & 1.2 \\
\hline
\end{tabular}


TABLE 15. Experimental values of apparent molar enthalpies, $\frac{\mathrm{H}}{\text { sodium dodecyl sulfate in } 0.17158 \mathrm{~m} \mathrm{NaCl} \text { at } 30^{\circ}}, \frac{\mathrm{C}}{\mathrm{C}}$

\begin{tabular}{|c|c|c|c|c|c|}
\hline $\begin{array}{l}\text { Initial molality, } \\
\text { mol }\left(\mathrm{kg} \mathrm{H}_{2} \mathrm{O}^{-1} \times 10^{2}\right.\end{array}$ & $\begin{array}{c}-\mathrm{H}_{6^{\prime}} \\
\mathrm{cal} \mathrm{mol}-1 \\
\end{array}$ & $\begin{array}{c}\text { Final molality, } \\
\mathrm{mol}(\mathrm{kg} \mathrm{H} \\
2\end{array}$ & $\begin{array}{c}-\mathrm{H}_{\phi^{\prime}} \\
\text { cal mol } \\
\end{array}$ & $\begin{array}{c}\Delta H \text { (measured), } \\
\mathrm{cal} \mathrm{mol}^{-1} \\
\end{array}$ & $\begin{array}{c}-\Sigma, \\
\mathrm{cal} \mathrm{mol}^{-1} \\
\end{array}$ \\
\hline 9.4616 & $\begin{array}{l}1020.0 \\
1020.0\end{array}$ & 6.7131 & 997.9 & 24.1 & 2.0 \\
\hline 9.4616 & 1020.0 & 5.7608 & 989.0 & 33.7 & 2.7 \\
\hline 9.4616 & 1020.0 & 4.8118 & 974.4 & 49.1 & 3.5 \\
\hline 9.4616 & 1020.0 & 3.8669 & 956.1 & 68.2 & 4.3 \\
\hline 9.4616 & 1020.0 & 2.9266 & 935.2 & 90.0 & 5.2 \\
\hline 5.9112 & 991.0 & 3.5156 & 954.7 & 38.3 & 2.0 \\
\hline 5.9112 & 991.0 & 2.9236 & 935.2 & 58.4 & 2.6 \\
\hline 5.9112 & 991.0 & 2.6282 & 923.7 & 70.2 & 2.9 \\
\hline 5.9112 & 991.0 & 2.3332 & 915.2 & 79.0 & 3.2 \\
\hline 3.1335 & 942.0 & 1.5454 & 867.9 & 75.7 & 1.6 \\
\hline 3.1335 & 942.0 & 1.2323 & 836.7 & 107.2 & 1.9 \\
\hline 3.1335 & 942.0 & 0.9197 & 790.9 & 153.3 & 2.2 \\
\hline 2.7522 & 929.0 & 1.6859 & 871.5 & 58.5 & 1.0 \\
\hline 2.7522 & 929.0 & 1.4103 & 856.1 & 74.2 & 1.3 \\
\hline 2.7522 & 929.0 & 1.1352 & 821.0 & 109.6 & 1.6 \\
\hline 2.7522 & 929.0 & 0.8604 & 776.9 & 154.0 & 1.9 \\
\hline 1.8890 & 883.0 & 1.3471 & 847.6 & 36.0 & 0.6 \\
\hline 1.8890 & 883.0 & 1.1579 & 827.7 & 56.1 & 0.8 \\
\hline 1.8890 & 883.0 & 0.9689 & 797.4 & 86.6 & 1.0 \\
\hline 1.8890 & 883.0 & 0.7801 & 752.7 & 131.5 & 1.2 \\
\hline 1.8890 & 883.0 & 0.5914 & 693.6 & 190.8 & 1.4 \\
\hline 0.9709 & 800.0 & 0.4801 & 639.9 & 160.6 & 0.5 \\
\hline 0.9709 & 800.0 & 0.3830 & 562.2 & 238.4 & 0.6 \\
\hline 0.9709 & 800.0 & 0.2860 & 445.1 & 355.6 & 0.7 \\
\hline 0.5134 & 660.0 & 0.3053 & 514.1 & 146.1 & 0.2 \\
\hline 0.5134 & 660.0 & 0.2540 & 377.2 & 283.1 & 0.3 \\
\hline 0.5134 & 660.0 & 0.1513 & 88.4 & 572.0 & 0.4 \\
\hline 0.4000 & 580.0 & 0.1979 & 224.3 & 355.9 & 0.2 \\
\hline 0.4000 & 580.0 & 0.1179 & 4.3 & 576.0 & 0.3 \\
\hline 0.4000 & 580.0 & 0.0979 & -6.9 & 587.2 & 0.3 \\
\hline
\end{tabular}


TABLE 16. Critical micelle concenitrations for sodium dodecyl sul fate

\begin{tabular}{lcrcr} 
& \multicolumn{4}{c}{$\mathrm{cmc}, \mathrm{mol}:\left(\mathrm{kg} \mathrm{H}_{2} \mathrm{O}\right)^{-1} \times 10^{3}, \pm 0.5$} \\
\cline { 2 - 5 } Background & $\frac{20^{\circ} \mathrm{C}}{8.1}$ & $\frac{25^{\circ} \mathrm{C}}{8.3}$ & $\frac{30^{\circ} \mathrm{C}}{8.4}$ & $\frac{35^{\circ} \mathrm{C}}{8.3}$ \\
$\mathrm{H}_{2} \mathrm{O}$ & 7.4 & - & 7.8 & - \\
$0.001 \mathrm{~m} \mathrm{NaCl}$ & 4.4 & - & 4.9 & - \\
$0.01 \mathrm{~m} \mathrm{NaCl}$ & - & - & 4.8 & - \\
$0.01 \mathrm{~m} \mathrm{NaBr}$ & 4.4 & - & 5.2 & - \\
$5 \% \mathrm{i}$-Propanol & 3.6 & 2.5 & - & - \\
$5 \%$ n-Butanol & & & &
\end{tabular}

TABLE 17. Selected values for sodium dodecyl sulfate

Molality,

$\frac{\mathrm{mol} \mathrm{kg}^{-1}}{0.0}$

0.005

$\mathrm{cmc}$

0.010

0.015

0.020

0.025

0.030

0.035

0.040

0.045

0.050

0.055

0.060

0.065

0.070

0.075

0.080

\begin{tabular}{|c|c|c|c|}
\hline \multicolumn{4}{|c|}{$L_{\phi}$, cal mol ${ }^{-1}$} \\
\hline $20^{\circ} \mathrm{C}$ & $25^{\circ} \mathrm{C}$ & $30^{\circ} \mathrm{C}$ & $35^{\circ} \mathrm{C}$ \\
\hline 0 & 0 & 0 & 0 \\
\hline 130 & 141 & 154 & 158 \\
\hline 199 & 169 & 195 & 197 \\
\hline 279 & 182 & 101 & 31 \\
\hline 421 & 154 & -99 & -327 \\
\hline 484 & 125 & -224 & -574 \\
\hline ו15 & 97 & -317 & -724 \\
\hline 520 & 72 & -387 & -827 \\
\hline 520 & 46 & -437 & -904 \\
\hline 516 & 22 & -479 & -964 \\
\hline 507 & 0 & -515 & -1011 \\
\hline 501 & -18 & -548 & -1053 \\
\hline 493 & -41 & -574 & -1089 \\
\hline 484 & -62 & -600 & -1121 \\
\hline 474 & -79 & -620 & -1149 \\
\hline 465 & -92 & -639 & -1174 \\
\hline 454 & -106 & -656 & -1194 \\
\hline 444 & -119 & -671 & -1214 \\
\hline
\end{tabular}




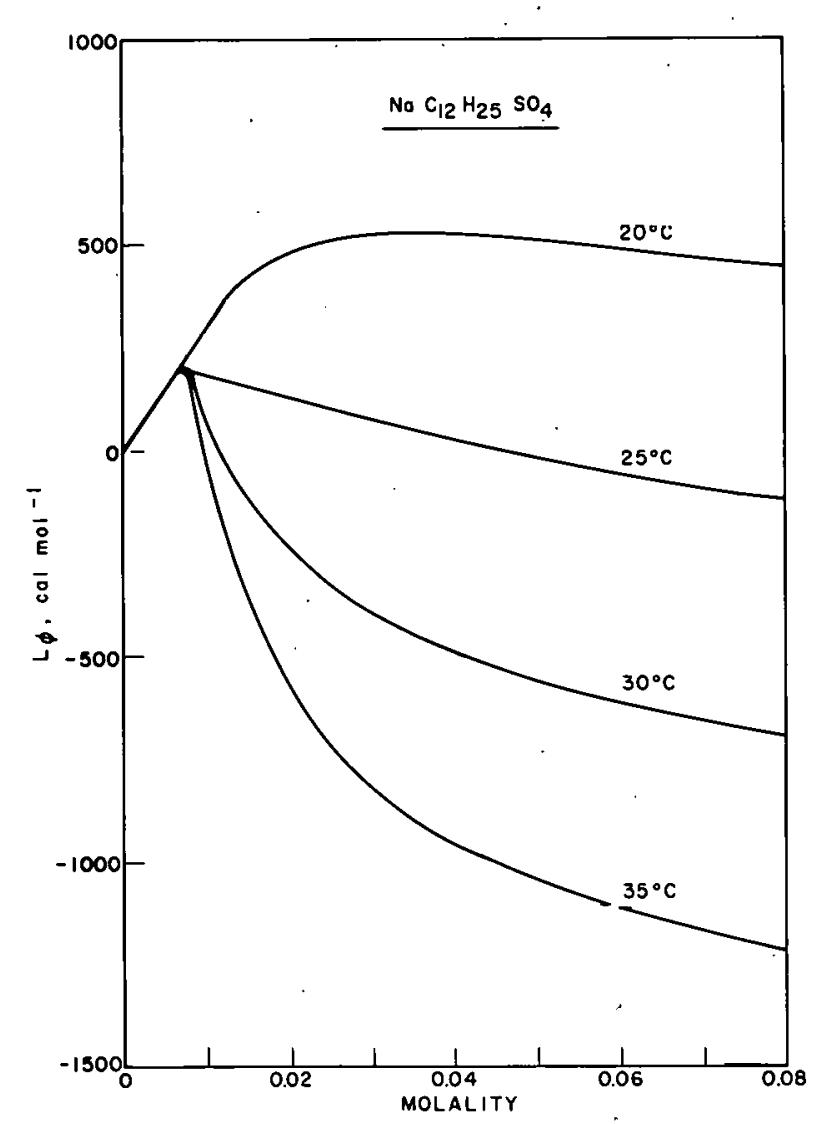

FIGURE 3. Sodium Dodecyl Sulfate Enthalpy Curves at Various Temperatures.

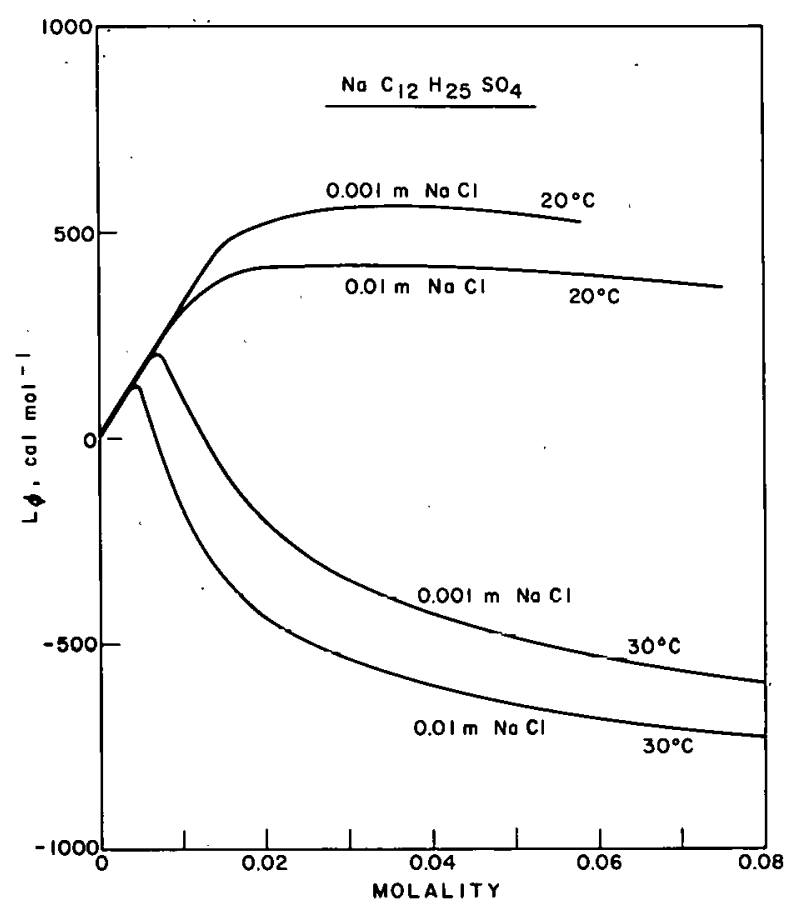

FIGURE 4. Sodium Dodecyl Sulfate Enthalpy Curves in Salt Background.

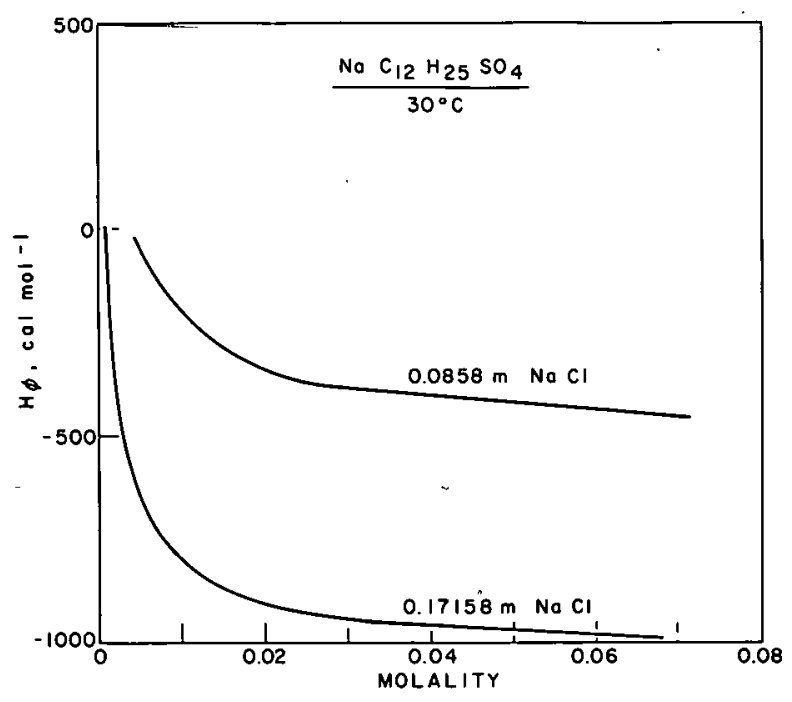

FIGURE 5. Sodium Dodecyl Sulfate Enthalpy Curves in High Salt Concentration Background. 

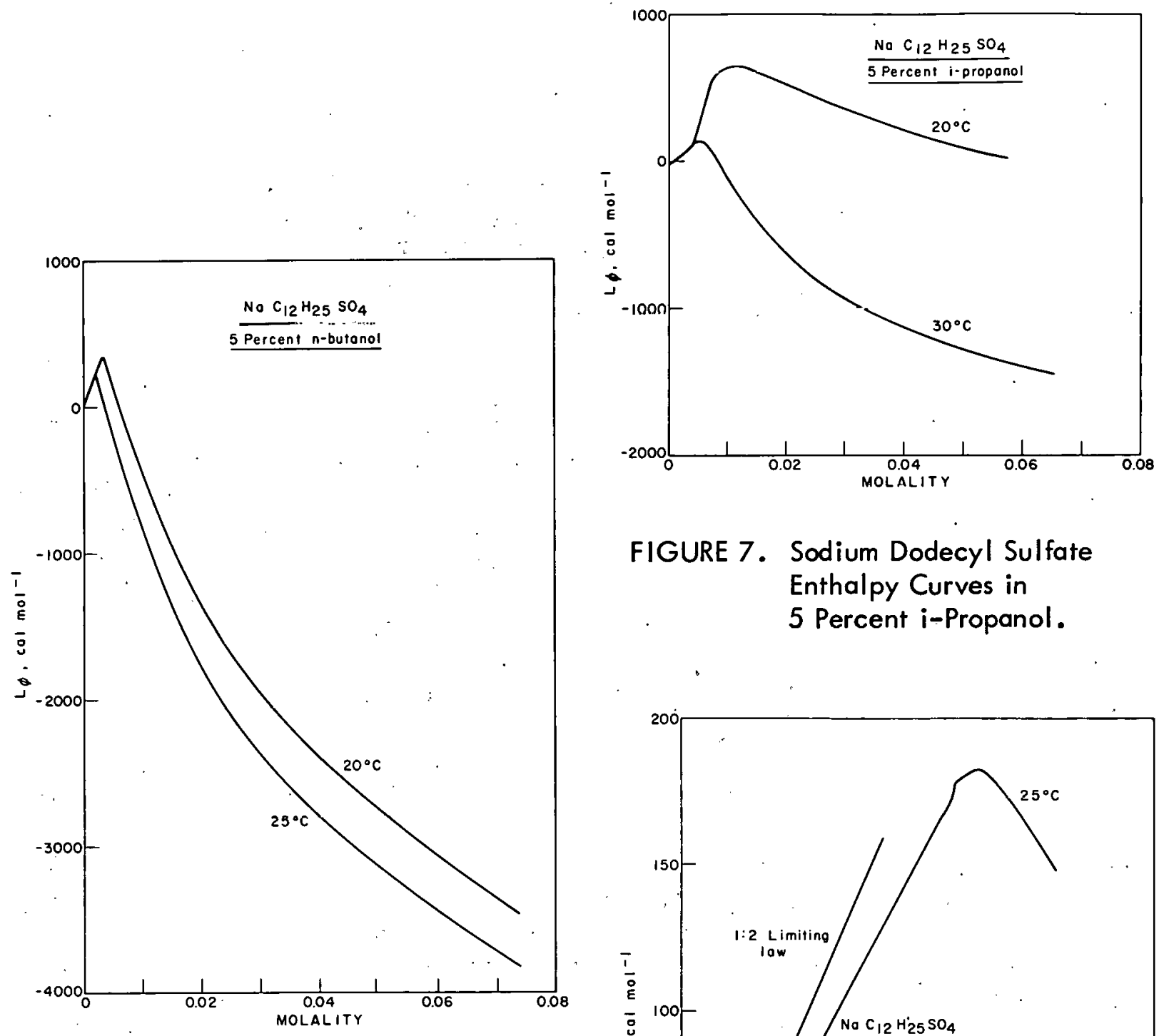

FIGURE 7. Sodium Dodecyl Sulfate Enthalpy Curves in 5 Percent i-Propanol.

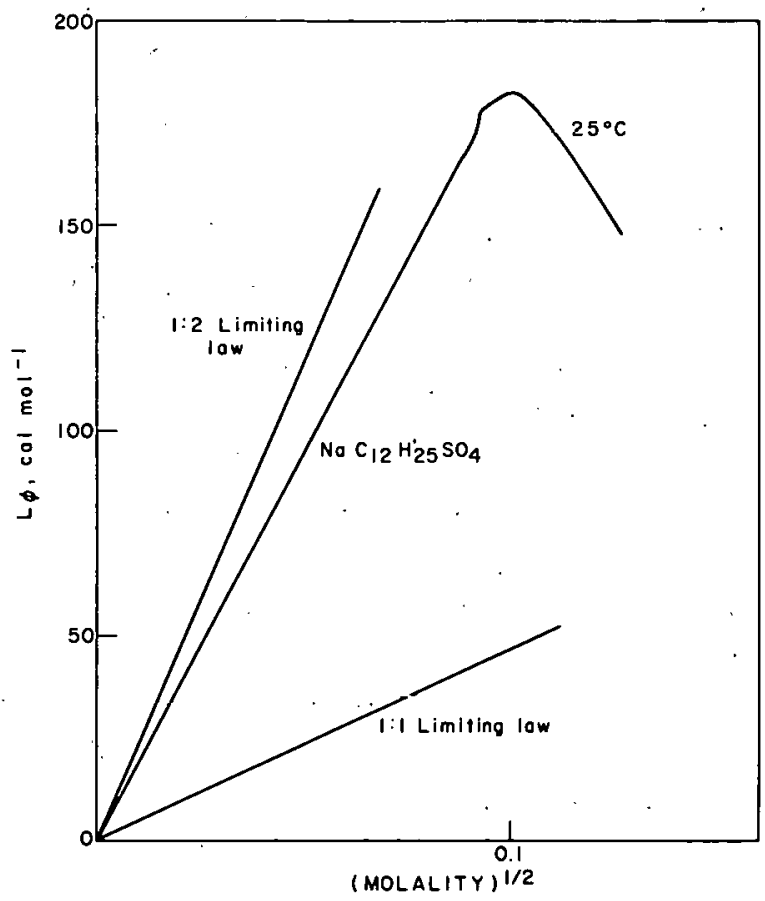

FIGURE 8. Sodium Dodecyl Sulfate Below the CMC. 


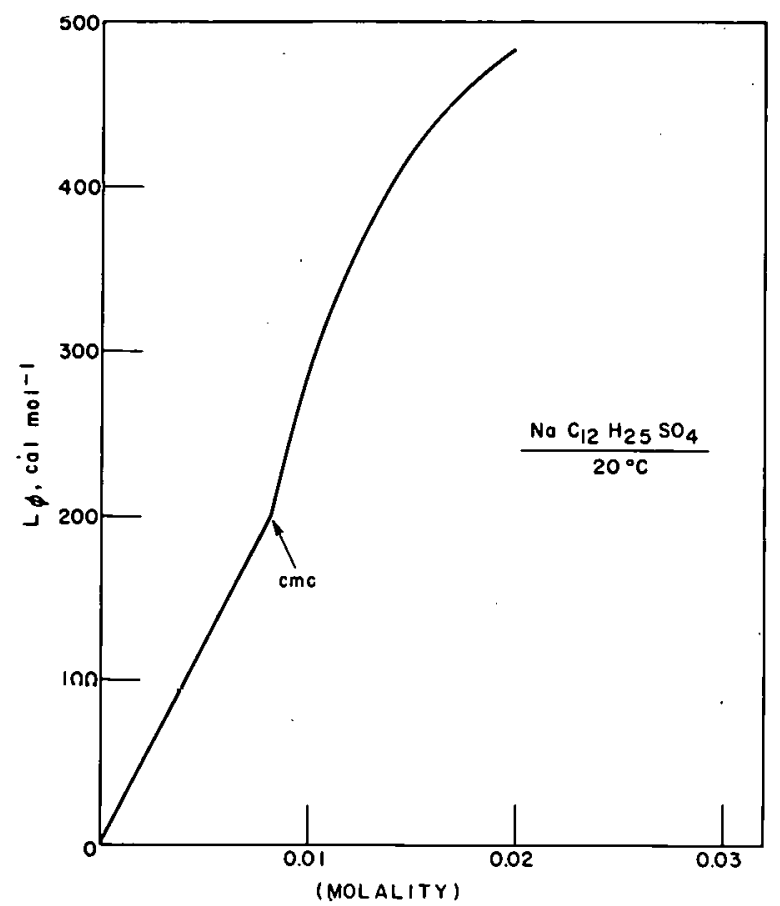

IGURE 9. Sodium Dodecyl Sulfate Enthalpy Curve at $20^{\circ} \mathrm{C}$.

\section{DISCUSSION}

\section{Observations}

Figure 3 shows the strong temperature dependence of the enthalpy of micellization of sodium dodecyl sulfate. Although the cmc is only slightly temperature dependent, the enthalpy terms demonstrate a strong dependence on temperature for the formation of the sodium dodecyl sulfate micelle. There is a slight temperature dependence below the $\mathrm{cmc}$ as the results of table 17 demonstrate. Figure 8 shows at $25^{\circ} \mathrm{C}$ that there is a slight increase in the slope of the $L_{\phi}$ curve at the $\mathrm{cmc}$. This increase is more evident in the $20^{\circ} \mathrm{C}$ results shown in figure 9. At higher temperatures, $30^{\circ}$ and $35^{\circ} \mathrm{C}$, the curves fall off sharply at the $\mathrm{cmc}$.

A salt background has considerable effect on the dilution enthalpy curves as shown

in figures 4 and 5 . The $\mathrm{cmc}$ is lowered, and the curves are changed. In higher salt concentrations (figure 5), the curves drop off over a narrow concentration range and level off, whereas in lower salt concentrations the falloff is more gradual and leveling off occurs at higher concentrations of surfactant. This seems to indicate a higher degree. of stability in high salt concentration which would be expected because of the additional cation ability to neutralize the charge environment of the micelle. Measurements with $0.01 \mathrm{~m} \mathrm{NaBr}$ background give a congruent curve with the $0.01 \mathrm{~m} \mathrm{NaCl}$ results indicating that the anion has little influence on the interactions of the micelle.

Alcohols as cosurfactants have considerable effect on the enthalpy terms. The phenomena of solubilization of the micelle and its monomers is still poorly understood. Qualitatively it is observed that the longer chain alcohols increase the solubility of the surfactant more so than the shorter chain alcohols. This is most likely owing to an increased ability to shield the hydrocarbon tail of the surfactant from water molecules. Work on sodium dodecyl sulfonate currently in progress shows similar results with those in figures 6 and 7.

The results for the premicellar region have raised several questions regarding the possible existence of a dimer below the $\mathrm{cmc}$. The results seem to indicate that below the $\mathrm{cmc}$ a dimer is present rather than a monomer. The slopes of the dilution enthalpy curve, shown in figure 8, do not approach the Debye-Huckel limiting law slope for 1:1 charge 
type electrolytes. Additional terms associated with ion size parameters in extended fitting equations give an even larger discrepancy since the larger the ion, the smaller the slope of the theoretical $L_{\phi}$ curve. It is of considerable interest that the measured terms approach the slope of a $1: 2$ electrolyte. If the $L_{\phi}$ terms are plotted against $(\mathrm{m} / 2)^{\frac{1}{2}}$, assuming complete dimerization, the results lie on the $1: 2$ electrolyte curve. The formation of a dimer below the $\mathrm{cmc}$ has been speculated numerous times in the literature. These speculations have considered the possibility of a monomer-dimer equilibrium. The results reported here would suggest an irreversible dimer being the only species below the cmc. Such a species would not be detectable using conventional methods used for study below the cmc since the dimer would give a linear relationship for properties such as conductivity, surface tension, and viscosity. While calorimetric measurements in the low concentration region are difficult, the uncertainties are not large enough to allow the data to be forced into fitting the $1: 1$ electrolyte pattern. If the dimer does exist it is most likely a hydrocarbon tail overlap with the polar head groups having a maximum charge separation. Many questions regarding the monomer (or dimer) equilibria with the micelle remain unanswered. The hypothesis of a dimer is one possible answer to problems raised by several other investigations. Additional work in the premicellar region is being carried out with other anionic surfactants.

\section{Earlier Measurements}

One of the major difficulties in comparing thermodynamic measurements of micellization enthalpies results from the lack of data reported in the literature. Numerous calorimetric studies have been made; however, in many cases, the measured enthalpies have been mathematically manipulated to give a value for the enthalpy of micellization. Such manipulation; while valuable in testing theories, obscures the fact that the researchers may have used different methods to treat their data. As a result, each method may produce a different value. The methods briefly summarized are:

$$
\begin{aligned}
& L_{\phi} \text { (above cmc) - } L_{\phi} \dot{\phi} \text { (below cmc), } \\
& \mathrm{L}_{\phi} \text { (above cmc) }-\mathrm{L}_{\phi}^{0} \text {, } \\
& L_{\varnothing} \text { (above cmc) - } \Delta H \text { (ion-pairing) - } L_{\varnothing} \text { (dilution), } \\
& \bar{L} \text { (above cmc) - E (below cmc), } \\
& \bar{L} \text { (above cmc) - } \overleftarrow{\mathrm{L}}^{0} \text {, } \\
& \bar{L} \text { (above cmc) - } \Delta H \text { (ion-pairing), }
\end{aligned}
$$

where $[$ terms are partial molal enthalpies, and another method which calculates the enthalpy for adding 1 mole of monomer to the micelle.

The results reported here for the premicellar region are in good agreement with the results presented graphically by Birch and Hall (1). Since they report no experimental values, 
it is not possible to make direct numerical comparisons of the values for the $L_{\phi}$ terms. The large deviation from the Debye-Huckel llimiting law observed in their results is also seen in the results reported here.

The work of Skewis and Zettlemoyer (25-26) on sodium dodecyl sulfate adsorption on graphon surfaces includes several measurements of dilution enthalpies for the surfactant. The results are in agreement with our results, but their measurements have a larger uncertainty associated with them.

The work of Pilcher (22) includes measurements of the enthalpies of dilution and mixing of sodium dodecyl sulfate. He reports a value of $-(55 \pm 2) \mathrm{cal} \mathrm{mol}^{-1}$ for the dilution below the $\mathrm{cmc}$ to infinite dilution at $23^{\circ} \mathrm{C}$. This value is in disagreement with our values below the $\mathrm{cmc}$; however, we obtain a value of $-50 \mathrm{cal} \mathrm{mol}^{-1}$ for dilution from below the $\mathrm{cmc}$ to a concentration equal to half the $\mathrm{cmc}$. His notation for micellization

$$
2\{0,1\}=\{1,1\}+\{0,0\}
$$

converts to

$$
2 \mathrm{NaC}_{12} \mathrm{H}_{25} \mathrm{SO}_{4}(0.008 \mathrm{~m}) \rightarrow 2 \mathrm{NaC}_{12} \mathrm{H}_{25} \mathrm{SO}_{4}(0.016 \mathrm{~m})
$$

for which he obtains $-609 \mathrm{cal} \mathrm{mol}^{-1}$ at $30^{\circ} \mathrm{C}$. The results reported here give -630 $\mathrm{cal} \mathrm{mol}{ }^{-1}$ for the same reaction. At $25^{\circ} \mathrm{C}$ the agreement is much poorer. He reports $+87 \mathrm{cal} \mathrm{mol}^{-1}$ versus $-40 \mathrm{cal} \mathrm{mol}^{-1}$ using table 17. In Pilcher's work, the sample was recovered from solution, and at the end of the series of measurements a purity check did indicate a minimum in the surface tension versus concentration curve. The investigators did not feel that this produced a significant error in the results. No attempts to avoid hydrolysis are mentioned.

The value of Eatough and Rehfeld (3) for the enthalpy of micellization at the $\mathrm{cmc}$ is $0.52 \pm 0.04 \mathrm{kcal} \mathrm{mol}^{-1}$ at $25^{\circ} \mathrm{C}$. They have separated the ir calorimetric titration heat effect into an enthalpy of micellization and an enthalpy of ion pairing and have derived an ion-pairing equilibrium constant. No correction for dilution of the monomer below the $\mathrm{cmc}$ is used in their work. The separation of the micellization from the ion pairing is dependent on activity coefficients and micelle number. For the present, we prefer to report enthalpy of micellization values without correction for the ion pairing. It is obvious that ion pairing does occur since the presence of a clump of 50 to 60 charge units (3) existing freely in solution is electrostatically highly unfavorable. The question of how the charge is neutralized and to what extent is still unanswered. Eatough and Rehfeld's graphical presentation of measurements by "conventional" calorimetry are in good agreement with the values reported in itable 2.

The calorimetric study of Paredes (20) gives a value of $162 \mathrm{cal} \mathrm{mol}^{-1}$ for the enthalpy of micellization at $25^{\circ} \mathrm{C}$. This value is obtained after considerable mathematical treatment to separate dilution terms for the mongmer and the micelle. The general shape of their enthalpy measurement curve is in aggeement with our results. However, an exact 
comparison is not possible because of uncertiainty in the interpretation of their graphs. Their mathematical determination of enthulpies of dilution is open to question, particularly since the equation which they describej as "Owen's equation" cannot be obtained from the equations given by Owen (19).

The 1956 work of Goddard and Benson (5) ion enthalpies of solution of sodium dodecyl sulfate to give final solutions of different concentrations was re-examined by the original authors (5) in 1957. They state that the work should be repeated to eliminate several errors in the measurements; however, no. luteri measurements have been located in the literature.

Comparison of the average heat capacities calculated here with the measured values of Musbally, Perron, and Desnoyers (17) shows good agreement in the shape of the heat capacity versus concentration curve. A small shift of $-11 \mathrm{cal} \mathrm{K}^{-1} \mathrm{~mol}^{-1}$ in their $\mathrm{C}_{\phi^{\circ}}$ brings the results into excellent agreement. In a 1976 paper by the same authors (18), a value of $-126.7 \mathrm{cal} \mathrm{K}^{-1} \mathrm{~mol}^{-1}$ is given in contrast to the value of $-123.3 \mathrm{cal}$ $\mathrm{K}^{-1} \mathrm{~mol}^{-1}$ in the original work. The $-112 \mathrm{cal} \mathrm{K}^{-1} \mathrm{~mol}^{-1}$ calculated here is in good agreement with their value of $-110 \mathrm{cal} \mathrm{K}^{-1} \mathrm{~mol}^{-1}$ from a recalculation of their results with a shift of $C_{\phi^{\circ}}$. The value is strongly dependent on the method of calculating $\Delta C_{m}$ whether from differences in

$$
\begin{aligned}
& C_{\phi}\left(\text { above cmc) }-C_{\phi}{ }^{\circ},\right. \\
& C_{\phi}\left(\text { above cmc) }-C_{\phi}\right. \text { (below cmc) } \\
& \bar{C} \text { (above cmc) }-\bar{C}^{\circ}, \text { or } \\
& \bar{C} \text { (above cmc) }-\bar{C} \text { (below cmc) }
\end{aligned}
$$

where $\bar{C}$ 's are partial molal heat capacities and $C_{\varnothing}$ 's are apparent heat capacities.

The value for the change in heat capacity of micellization of $-134 \mathrm{cal} \mathrm{K}^{-1} \mathrm{~mol}^{-1}$ reported by Kresheck and Hargraves (12) using a titration calorimeter is in excellent agreement with the results reported here using relationship 15. Use of their method of calculating the enthalpy of micellization $\left(\bar{H}^{\prime}(\right.$ above $\left.\mathrm{cmc})-\overline{\mathrm{H}}^{\circ}\right)$ on the results reported here gives values of $-0.46 \mathrm{kcal} \mathrm{mol}^{-1}$ at $25^{\circ} \mathrm{C},-0.92 \mathrm{kcal} \mathrm{mol}-1$ at $30^{\circ} \mathrm{C},-1.58 \mathrm{kcal}$, $\mathrm{mol}^{-1}$ at $35^{\circ} \mathrm{C}$ in excellent agreement with their values of $-0.51,-0.96$, and -1.69 . Their solutions were $\mathrm{pH}$ adjusted, and no mention is made of attempts to avoid hydrolysis (8) .

\section{PLANNED STUDIES}

Future work in the area of thermodynamics of surfactant systems will concentrate on alkyl and alkyl aromatic sulfonates of the type commonly found in petroleum sulfonates. The effects of cosurfactant and brine backgrounds will be explored. Studies are planned with mixed micellar systems and with micelles in hydrocarbon backgrounds. Work on adsorption of surfactants on clay and sand surfaces is in progress. 


\section{SUMMARY}

A microcalorimeter system has been assembled and put into operation for a study of micellar systems. Dilution enthalpy measurements on sodium dodecyl sulfate over a temperature range of $20^{\circ}$ to $35^{\circ} \mathrm{C}$ in several background media are reported. Questions regarding the behavior of the dilution curves have been raised and possible qualitative explanations given.

\section{ACKNOWLEDGMENT}

This work is funded by the Division of Oil, Gas, and Shale Technology of the U.S. Energy Research and Development Administration. 


\section{REFERENCES}

1. Birch, B. J., and D. G. Hall. Heafs sof Dilution of Sub-micellar Aqueous Surfactant Solutions. Trans. Faraday: Soc. 1, v. 68, 1972, pp. 2350-2355.

2. Dreger, E. E., G. I. Keim, G. D. Miles, L. Shedlovsky, and J. Ross. Sodium Alcohol Sulfates - Properties Invollving Surface Activity: Ind. Eng. Chem., v. 36, 1944, p. 610 .

3. Entough, D. J., and S. J. Rehfeld, A Calorimetric Investigation of Micelle Formation in Aqueous Sodium Dodecylsulfate Solutions. Thermochimica Acta, v. 2, 1971, pp. 443-456.

4. Goddard, E. D., and G. C. Benson, Heat of Micelle Formation of Sodium Dodecyl Sulphate. Trans. Faraday Soc., v. 52, 1956, pp. 409-413.

5. Goddard, E. D., C.A. J. Hoeve, and G. C. Benson. Heats of Micelle Formation of Paraffin Chain Salts in Watier. J. Phys. Chem., v. 61, 1957, p. 61.

6. Gogarty, W. B., and W. C. Tosch: Miscible-Type Waterflooding: Oil Recovery with Micellar Solutions. J. Petrol. Technol., v. 20, 1968, p. 1407.

7. Gucker, F. T., Jr., H. B. Pickard, and R. W. Planck. A New Micro-Calorimeter: The Heats of Dilution of Aquéeous Solutions of Sucrose at $20^{\circ}$ and $30^{\circ}$ and,

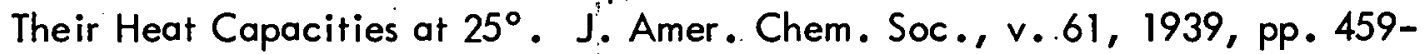
470.

8. Hargraves, W. A. Studies on the Binding of Anionic, Cationic, and Nonionic Alkyl Detergents to Poly ( $n$-Vinyl Pyrrolidone) and $\beta$-Lactoglobulin by Continuous Enthalpy Titration: Ph.D. Thesis, Northern Illinois Univ., Dekalb, III., 1972, 255 pp.

9. Harned, H. S., and B. B. Owen. Physical Chemistry of Electrolytic Solutions. Reinhold Publishing Corp., New: York, 3rd ed., 1957, 803 pp.

10. Harrold, S. P. Purification of Sodium Dodecyl Sulfate. J. Colloid Sci,, v. 15, 1960, p. 280.

11. Johnson, R. E., and R. L. Biltonen. Determination of Reaction Rate Parameters by Flow Microcalorimetry. J. Arner. Chem. Soc., v. 97, 1975, pp. 23492355. 
12. Kresheck, G. C., and W. A. Hargraves. Thermometric Titration Studies of the Effect of Head Group, Chain Length, Solvent, and Temperature on the Thermodynamics of Micelle Formation. J. Coll. Inter. Sci., v. 48, No. 3, 1974, pp. 481-493.

13. Leung, W. H., and F. J. Millero. The Enthalpy of Dilution of Some 1-1 and 2-1 Electrolytes in Aqueous Solution. J. Chem. Thermodynamics, v. 7, 1975, pp. 1067-1078.

14. Meister, M. J., G. K. Kettenbrink, and A. G. Collins. Enhanced Oil Recovery Using Improved Aqueous Fluid-Injection Methods: An Annotated Bibliography. BERC/IC-76/3, 1976, 149 pp.

15. Monk, P., and 1. Wadsö. A Flow Micro Reaction Calorimeter. Acta Chem. Scand., v. 22, No. 6, 1968, pp. 1842-1852.

16. Mukkerjee, P., and K. J. Mysels. Critical Micelle Concentrations of Aqueous Surfactant Systems. National Standard Reference Data Series, NBS 36, U.S. Government Printing Office, Washington, D.C., 1971.

17. Musbally, G., G. Perron, and J. E. Desnoyers. Apparent Molal Volumes and Heat Capacities of lonic Surfactants in Water at $25^{\circ} \mathrm{C}$. J. Coll. Inter. Sci., v. 48, 1974, p. 494.

18. - The Fffect of Temperature and Urea on the Apparent Molal Volumes and Heat Capacities of $n$-Nonyltrimethylammonium Bromide in Water. J. Cull. Inter. Sci., v. 54, 1976, p. 80.

19. Owen, B. B., and S. R. Brinkley, Jr. Extrapolation of Apparent Molal Properties of Strong Electolytes. Ann. N.Y. Acad. Sci., v. 51, 1949, p. 753.

20. Paredes, S., M. Tribout, J. Ferreira, and J. Leonis. A Microcalorimetric Method of Determination of Critical Micellar Concentration and Enthalpy of Micellization. Colloid and Polymer Sci., v. 254, 1976, pp. 637-642.

21. Parker, V. B. Thermal Properties of Aqueous Electrolytes. National Standard Reference Data Series, NBS 2, U.S. Government Printing Office, Washington, D.C., 1965.

22. Pilcher, G., M. N. Jones, L. Espada, and H. A. Skinner. Enthalpy of Micellization. I. Sodium n-Dodecylsulphate. J. Chem. Thermodynamics, v. 1, 1969, pp. 381-392. 
23. Picker, P. Axial Piston Rotary Apparatus. U.S. Patent 3,795, 179, March 5, 1974.

24. Prosen, E. J. Personal communication, January 1976.

25. Skewis, J. D. The Adsorption of Surfactant Anions and Gegenions to the Graphon/Aqueous Solution Interface. Ph.D. Thesis, Lehigh Univ., Bethlehem, Pa., 1959, 177 pp.

26. Skewis, J. D., and A. C. Zettlemoyer. Heats of Adsorption of Surfactant lons to the Graphon/Solution Interface. Chem. Physics \& Appl. of Surf. Active Sub., 3rd Congress Surface Act. Substances, v. 3, 1960, pp. 401-408. 